\title{
The Economics of Foreign Aid: Time Series Evidence from a Less Developed Country (LDC)
}

\author{
Md Mahadee Hassan ${ }^{1}$ \\ 'Deputy Secretary, Economic Relations Division, Ministry of Finance, and Government of Bangladesh
}

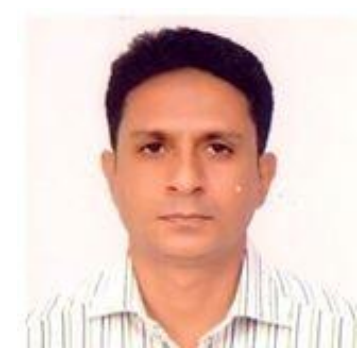

\begin{abstract}
Empirical literature on aid-growth nexus mostly centered within cross-country framework exploiting typical ordinary least squares (OLS) estimation. As a result, scarcity prevails studies empirically examine country-specific causes of aid-growth nexus exercising distinct methods. This study aims to fill this gap, taking the case of Bangladesh- a leading aid recipient country. Empirical findings based on vector error correction modeling and Granger causality test unearth absence of long-run and short-run causality of aid on GDP growth. Therefore, this study argues that although aid remains a major component of LDCs macroeconomic framework; however, it is yet to emerge as a significant player in their economic growth.
\end{abstract}

Keywords: Aid-growth nexus, Vector error correction modeling, Causality, Bangladesh.

Citation | Md Mahadee Hassan (2017). The Economics of Foreign Aid: Time Series Evidence from a Less Developed Country (LDC) Asian Journal of Economics and Empirical Research, 4(2): 75-90. History:

Received: 1 October 2017

Revised: 13 October 2017

Accepted: 18 October 2017

Published: 23 October 2017

Licensed: This work is licensed under a Creative Commons

Attribution 3.0 License $(\mathrm{cc})$ )

Publisher:Asian Online Journal Publishing Group
Funding: This study received no specific financial support.

Competing Interests: The authors declare that they have no conflict of interests.

Transparency: The authors confirm that the manuscript is an honest, accurate, and transparent account of the study was reported; that no vital features of the study have been omitted; and that any discrepancies from the study as planned have been explained.

Ethical: This study follows all ethical practices during writing.

\section{Contents}

1. Background

2. Aid-Growth Models, Instrumentation, and Estimation Strategies 76

3. Methodologies 77

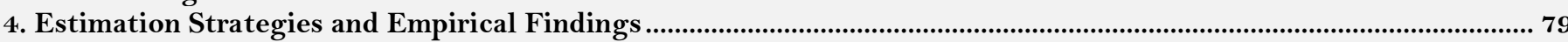

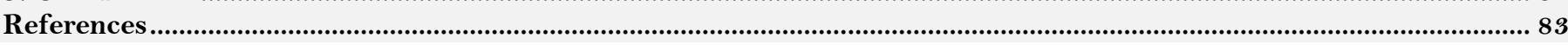




\section{Background}

'Foreign aid' popularly known as official development assistance (ODA) is a saga of over seven decades (Dalgaard et al., 2004). Starting its expedition at the end of World War Two (WW2) and intensifying in 1960s and since then aid-growth nexus has been staying a key area of research interests (Boone, 1996; Alesina and Dollar, 2000; Dalgaard et al., 2004; Doucouliagos and Paldam, 2009). For example, last five decades (1960- 2010) have witnessed a revolution in aid-growth paradigms where record number of cross-country growth regressions proved insufficient justifying aid effectiveness (or ineffectiveness) (Sala-i-Martin, 1997a;1997b; Hansen and Tarp, 2000; Clemens et al., 2004; Hendry and Krolzig, 2004). Major reasons of this aid-growth impasse is because of great controversies in model specification, instrumentation and estimation strategies (Easterly, 2003; Bourguignon and Sundberg, 2007; Rajan and Subramanian, 2008; Deaton, 2010; Galiani et al., 2014). More pertinently, studies before 1990 s were unable to draw adequate inferences due to shortage of data, and standard instrumentation and estimation strategies (Easterly, 2003). While, considering donors' point of views, growth is absent in the core of their major aid agendas. Instead, development assistance largely extended to respond emergency and humanitarian needs, and these sorts of external resources normally originate negative causal link towards growth (Clemens et al., 2004). In addition, aid packages frequently designed to serve other purposes including promoting political systems, supporting democracies, and addressing health and environmental issues. Although, growth is prompted around those kinds of aid but hardly in the long run (Clemens et al., 2004). However, Alesina and Dollar (2000) find nothing significant regarding humanitarian role of aid and argue that it is simply continuing to serve political motives and this notion strongly supported by Rajan and Subramanian (2008) who branded 'political motives' as noneconomic reasons. Final category of Clemens et al. (2004)classified foreign aid is exploited for productive purposes and in particular, supporting budget, balance of payments, and invests in infrastructure and other development projects. Research evidence suggests that this type of development assistance maintain robust short run causal link towards economic growth (Clemens et al., 2004).

Aid effectiveness literature (AEL) ${ }^{1}$ has come across a number of phases reaching its extant form (Clemens et al., 2004; Roodman, 2007). Classification of those phases magnificently recorded in a good number of outstanding literature notably in Doucouliagos and Paldam (2009);Roodman (2007);Clemens et al. (2004) and Hansen and Tarp (2000). These exceptional works label the phases as; early, first, second and third generation. Early stage includes studies of 1960 s predominantly explain impact of aid on savings and investments rather than examining its effectiveness on growth (Clemens et al., 2004; Roodman, 2007; Doucouliagos and Paldam, 2009). This early phases' particular academic interest intensified due to the influences of Harood-Domar model, where significance of savings on growth has been strongly argued (Roodman, 2007). Two pioneering early studies are, Rosenstein-Rodan (1961) and Chenery and Strout (1966). Among the authors, Rosenstein-Rodan and Chenery held World Banks' chief economist position one time each. While, Hansen and Tarp (2000) identify that first generation studies ranging from early 1970 s to 1980 s also focusing on aid-savings link, and major works include Griffin and Enos (1970); Weisskopf (1972); Papanek (1972); Papanek (1973); Griffin (1978); Gulati (1978) and Mosley (1980). Second generation studies counting from early 1980 s to early 1990 s explore aid effects on investments and growth, and this generation dominated by a number of works of Mosley $(1986 ; 1987)$ and Mosley et al. (1987). Finally, third generation begins with Boone (1996) and continuing tills the date.

Although, AEL has a vibrant legacy; however, this paper centered mainly within third generation works. More importantly, third generation AEL enter in a new order with the emergence of 'conditional growth studies' in early 2000s (Easterly, 2003). Burnside and David (2000) led this uprising and more significantly, majority of third generation AEL organized in such a fashion keeping (Burnside and David, 2000) 'influential' conclusions that 'aid works better in good policy environments', in the middle (Easterly et al., 2003). On the other hand, most of the AEL based on cross-country empirics exploiting typical OLS estimation (Hansen and Tarp, 2001; Doucouliagos and Paldam, 2009). In addition, more difficulties would appear when OLS estimations deliver 'spurious' outcomes (Wassell and Saunders, 2005). For this reason, scholars and practitioners express their reservations capitalizing conventional OLS estimations in policy implications due to 'unclear and ambiguous results' (Bourguignon and Sundberg, 2007). Accordingly, major objectives set for this study consist of estimating development assistances' impact on growth within country-specific framework through applying a logical instrumentation approach. Moreover, we want to employ rational estimation strategies which have the mechanisms of amending typical OLS estimation errors. In doing so, we adopt popular econometric methodologies of augmented Dickey-Fuller (ADF) test, Johansen test of cointegration, vector error correction modeling (VECM), and Granger causality test. Selecting the case, we consider size of the economy, stability in growth, population, and volume of development assistance. We take Bangladesh, an economy of $\$ 227$ billion $^{2}$ identified as one of the new growth-engines of Asia ${ }^{3}$ experienced an average GDP growth over 6 per cent $(6.22 \%)^{4}$ for the last ten years (2007-2016), and forecasts show that she will grow at the rate of 7 per cent $(7 \%)^{5}$ in the next six years (2017-2022) also (International Monetary Fund (IMF), 2017). More importantly, Bangladesh is a major aid-recipient country who consistently manages sizable amount of development assistance measuring nearly 2 per cent $(1.5 \%)$ of $\mathrm{GDP}^{6}$ during the period of 2005 to 2014 (World Bank, 2017).

Remainder of the article is structured as follows: section 2 reviews major aid effectiveness literature focusing on models, instrumentation and estimation strategies adopted there. Section 3 deals with this works' modeling and instrumentation strategies. Section 4 runs an exclusive analysis on estimation strategies, and present and discuss empirical findings. Finally, section 5 summarizes the findings and makes concluding remarks.

${ }^{1}$ We take the term AEL from Doucouliagos and Paldam (2009).

${ }^{2}$ According to IMF World Economic Outlook 2017, volume of Bangladesh's GDP in 2016 stands at \$227 billion

${ }^{3}$ In his inaugural speech at the Asian Development Bank (ADB) 50 th Board of Governors annual meeting on 6 May 2017 at Yokohama, Japan, President

Takehiko Nakao outlines six member countries as the new growth-engines of Asia. Among the six countries Bangladesh is one of them. Other five countries are: India, Indonesia, Myanmar, the Philippines and Vietnam (source: http://www.thedailystar.net/frontpage/asias-new-growth-engines-140172 1)

${ }^{4}$ Authors' calculation based on IMF World Economic Outlook 2017

${ }^{5}$ Authors' calculation based on IMF World Economic Outlook April 2017

${ }^{6}$ Authors' calculation based on World Bank World Development Indicators 2017 


\section{Aid-Growth Models, Instrumentation, and Estimation Strategies}

After surveying vast pile of AEL we find that numerous arguments derived in the formulation of aid-growth strategies. Majority of those debates are well documented in two classic studies of Deaton (2010) and Doucouliagos and Paldam (2009)who systematically scrutinize the methods applied in key aid-growth studies. Ultimately, a consensus emerged from this couple of documents along with other relevant literature that test of aid effectiveness on economic growth has been a regular practice of typical OLS estimation within cross-country framework using standard growth regressions (Hansen and Tarp, 2000; Hendry and Krolzig, 2004; Doucouliagos and Paldam, 2009; Deaton, 2010). As a result, organizing our review initially we focus on highly exploited typical Barro (1991) crosscountry growth regression commonly outlined in the form of:

$$
\gamma=\alpha+\beta_{1} \cdot \mathrm{x}_{1}+\beta_{2} \cdot \mathrm{x}_{2}+\ldots \ldots \ldots \ldots+\beta_{\mathrm{n}} \cdot \mathrm{x}_{\mathrm{n}}+\varepsilon
$$

In this model $\gamma$ represents the vector of rates of economic growth, $\alpha$ is the constant, and $x_{1}, \ldots, x_{n}$ are vectors of explanatory variables usually have different numbers and forms depend on the characteristics of particular research work and author (Doppelhofer et al., 2000). While, in classical aid-growth strategy, growth means real GDP growth, universally expressed in terms of GDP per capita (Doucouliagos and Paldam, 2009). Examining contemporary aid-growth strategies we want to concentrate on legendary work of Deaton (2010). Deaton (2010) aid-growth strategy structured in the form of following expression:

$$
\Delta \mathrm{InY}_{\mathrm{ct}+1}=\beta_{0}+\beta_{1} \operatorname{InY}_{\mathrm{ct}}+\beta_{2} \frac{\mathrm{I}_{\mathrm{ct}}}{\mathrm{Y}_{\mathrm{ct}}}+\beta_{3} \mathrm{H}_{\mathrm{ct}}+\beta_{4} Z_{\mathrm{ct}}+\theta \mathrm{A}_{\mathrm{ct}}+\mu_{\mathrm{ct}}
$$

Where $Y$ is the per capita GDP, $I$ represent investments, $H$ is an indicator of measuring human capital, $A$ is the ratio denoting share of aid to GDP, and $Z$ remains for other control variables. In addition, subscripts $c$ stands for country and $t$ for time. Deaton (2010) acknowledges that this approach basically an extension of Solow growth model except the inclusion of $A$, and $Z$ variables. Deaton (2010) is extremely critical regarding instrumentation strategies but praises (Boone, 1996) who pioneers employment of standard set of instruments in growth regressions. Estimating country-specific effects (Boone, 1996) uses several dummies and incorporates log of population size. Defending the significance of population size, Deaton (2010) argues that aid is extended primarily on the country basis, instead of considering size of the population. Hence, populous countries per capita aid receipt is lower than those of less-populated countries, and it bears great significance since, performance of aid frequently evaluated on the basis of per capita GDP. Therefore, influenced by Boone (1996) next generation influential aidgrowth studies ${ }^{7}$ widely capitalize both of GDP per capita and population size or one of these variables in their growth regressions (Deaton, 2010). However, Deaton (2010) is not convinced with the quality of instruments overcoming 'exogeneity' and 'heterogeneity' problems, and identifies inadequacy of standard theories validating the competency of instruments. Accordingly, Deaton (2010) conclude that with the current set of instruments it is quite challenging reaching to a robust conclusion on aid-growth nexus. Deaton (2010) raises all important concern that typical aid-growth estimation strategy considers whole volume of aid is duly invested. However, this is quite unrealistic, therefore, for better inferences, at first, it is required to identify the status of tangible investments and then to conclude on effectiveness. Another constraints noted, is the use of instrumental variables as Deaton (2010) shows great reservation in this regard; since, major AEL are in great jeopardy justifying the adoption of instrumental variable methods. Deaton (2010) warns that econometric estimation strategies changed drastically and centered merely within the statistical program evaluation packages rather than to focus on models originated from theories. Therefore, incorporation of instrumental variables in the estimation strategy creates severe disputes and which is leading to quasi-randomization (Deaton, 2010). Similarly, mishandling of instruments explode confusions and challenge the potentials of econometric analysis responding all important empirical enquiries (Deaton, 2010).

Let we concentrate on another exceptional survey of Doucouliagos and Paldam (2009) whose epic analysis on 97 econometric studies covering a period of four decades (mid-1960s to mid-2000s) summarizes overall standard aid-growth estimation strategy in the following form:

$$
\mathrm{g}_{\mathrm{it}}=\alpha+\mu \mathrm{h}_{\mathrm{it}}+\gamma_{\mathrm{j}} \mathrm{x}_{\mathrm{jit}}^{\prime}+\mathrm{u}_{\mathrm{it}}
$$

Explaining Equation-3, $g_{i t}$ is the real growth rate expressed in GDP per capita, $h_{i t}$ is the percentage aid to GDP/GNI, $x_{j i t}$ is the vector of $j$ control variable, and $u_{i}$ is the residuals, $\mu$ and $\mathrm{Y}$ are the two commonly estimated coefficients. More importantly, Doucouliagos and Paldam (2009) organize existing aid-growth models into three 'family' groups specified as 'accumulation', 'growth direct', and 'conditional'. Among those paradigms, 'accumulation' strategies frequently hypothesize that rise of domestic savings and balance of payment; particularly, 'accumulation' factors are vital for growth. The next family 'growth direct' is the overall model stated in equation3 , and more explicitly, while estimating 'accumulation' impact; growth of domestic savings $\left(\mathrm{s}_{\mathrm{it}}\right)$ and investments ( $\mathrm{i}_{\mathrm{it}}$ ) are measured instead of real GDP growth $\left(g_{i t}\right)$. Accordingly, this couple of 'accumulation' strategies frequently estimated in the form of following two equations:

$$
\begin{aligned}
& \mathrm{s}_{\mathrm{it}}=\alpha+\mu \mathrm{h}_{\mathrm{it}}+\gamma_{\mathrm{j}} \mathrm{x}_{\mathrm{jit}}^{\prime}+\mu_{\mathrm{it}} \\
& \mathrm{i}_{\mathrm{it}}=\alpha+\mu \mathrm{h}_{\mathrm{it}}+\gamma_{\mathrm{j}} \mathrm{x}_{\mathrm{jit}}+\mu_{\mathrm{it}}
\end{aligned}
$$

Apart from above aid-growth paradigms, emergence of 'good policy' studies led by Burnside and David (2000) surge most sensational arguments in aid effectiveness literature (Easterly, 2003; Clemens et al., 2004; Roodman, 2007). Undoubtedly, this development drives entire aid-growth debate into a new height, and Doucouliagos and Paldam (2009) place 'good policy' studies into the family of 'conditional growth model', and branded this group of scholars as 'World Bank group' since they are sponsored or somehow affiliated with aid industry ${ }^{8}$ World Bank. In 'good policy' paradigm it is strongly argued that aid is effective simply in good policy environments. Burnside and David (2000) 'good policy' strategy structured splendidly in Roodman (2007) in the following way:

${ }^{7}$ Deaton (2010). list of next generation studies includes Burnside and David (2000). Hansen and Tarp (2000;2001). Guillaumont and Chauvet (2001). Lensink and White (2001). Clemens, Radelet and Bhavnani (2004). Dalgaard, Hansen and Tarp (2004). Easterly, Levine and Roodman (2004). Roodman (2007). and Rajan and Subramanian (2008).

'Doucouliagos and Paldam (2009).Use the term 'aid industry' while branding influential aid organizations the World Bank, and Danish International Development Agency (DANIDA). 
$\Delta \mathrm{Y}=\alpha \mathrm{A}+\beta \mathrm{A} \times \mathrm{P}+\gamma \mathrm{P}+\mathrm{x} \delta+\varepsilon$

Where $Y$ is the per capita GDP, aid is represented by $A$, policy is denoted by $P, x$ is a vector of controls, and $\varepsilon$ is the error term. Similarly, Doucouliagos and Paldam (2009) prescribed 'good policy' models' unique feature is that it employs a right hand side 'good policy' variable $z$, and which is the good policy index of particular country comprising weighted sum of budget surplus, inflation rate, and trade openness. In addition, two more coefficients $\delta$ and $\omega$ are also estimated. Consequently, Doucouliagos and Paldam (2009) outline 'good policy' model estimation strategy in the following manner:

$$
\mathrm{g}_{\mathrm{it}}=\alpha+\mu \mathrm{h}_{\mathrm{it}}+\delta \mathrm{z}_{\mathrm{it}}+\omega \mathrm{h}_{\mathrm{it}} \mathrm{z}_{\mathrm{it}}+\gamma_{\mathrm{jit}} \mathrm{x}_{\mathrm{jit}}+\mathrm{u}_{\mathrm{it}}
$$

Regarding origins, Burnside and David (2000) approach based on neoclassical growth model, and their ever dominant theory suggests that aid works positively on growth until recipient country's GDP growth stays below the zenith of her transitional growth rate. According to Burnside and David (2000) negative impact of aid caused due to the presence of distortionary economic policies. Therefore, Burnside and David (2000) advocate for policy development achieving enhanced aid effectiveness, but they are not certain that inclusion of policy instruments will act properly because other factors can make whole spectrum complicated. However, Burnside and David (2000) two universal hypotheses are: aid and 'good policy' combination is most effective, and effects of 'good policy' triggered by foreign aid. While, corresponding 'good policy' study of Collier and Dollar (2002) analyze real aid allocation scenarios through developing a poverty-efficient aid allocation framework using World Bank ratings of aid recipient countries national policies on aid utilization plans. For example, a country with severe poverty but has good policies is fit to be in the priority of poverty-efficient aid allocation framework. Their findings suggest that existing aid allocation mechanisms is not poverty-efficient although, aid works magnificently bringing out millions of people from absolute poverty. Dollar and Kraay (2002) add a couple conditions to Burnside and David (2000) original variables precisely, stability in inflation and small government size. Overall, Dollar and Kraay (2002) conclude that governance, good trade policies, robust financial systems have little systematic effects on growth.

Another branch of 'conditional growth' studies pioneered by Dalgaard et al. (2004); Dalgaard and Hansen (2001); Hansen and Tarp (2001) and Hansen and Tarp (2000) employ different types of policy instruments in estimation strategies. For example, Dalgaard et al. (2004) claim that 'climate-related circumstances' are the vital factors prompting degree of growth. However, Dalgaard et al. (2004) remain in suspicion concerning the competence of policies in aid effectiveness. Their concluding remarks indicate that size and structural characteristics of aid inflow and policies 'may' influence aid effectiveness. Similar inferences also outlined in Hansen and Tarp (2001) as they suggest that aid has 'likelihood' influences on growth but not conditional on 'good policies'. More significantly, 'estimated' aid effectiveness highly depends on the set of exploited instruments. For instance, positive impact of aid is absent when 'investment' and 'human capital' is controlled. Overall, Hansen and Tarp (2001) suggest that extensive theoretical works on aid effectiveness require before capitalizing existing literature in policy formulations. Correspondingly, Hansen and Tarp (2000) widespread survey on three decades cross-country literature comprehensively examine aid-growth, aid-savings, and aid-investment relationships. After careful scrutiny, Hansen and Tarp (2000) confirm that Burnside and David (2000) 'good policy' model considerably discarded in existing empirical cross-country literature. Moreover, Hansen and Tarp (2000) explore that aid effectiveness is not conditional on good policies; instead, it also works significantly in such environments where good policies are absent. Dalgaard, Hansen, Tarp and fellow scholars' association with Danish International Development Agency (DANIDA) highlighted remarkably in Doucouliagos and Paldam (2009). Keeping consistency with the 'World Bank group' they are identified as 'DANIDA group', and their model labeled as 'Medicine Model' exploits an 'aid squared' term in the right hand side and more notably, aid is treated as a condition in the estimation strategies. Since, aid itself is a condition; therefore, Doucouliagos and Paldam (2009) empirically define 'Medicine Model' in the following way by reducing Equation 7:

$$
\mathrm{g}_{\mathrm{it}}=\alpha+\mu \mathrm{h}_{\mathrm{it}}+\omega \mathrm{h}_{\mathrm{it}}+\gamma_{\mathrm{jit}} \mathrm{X}_{\mathrm{jit}}^{\prime}+\mathrm{u}_{\mathrm{it}}
$$

\section{Methodologies}

\subsection{Model Specification and Instrumentation Strategy}

The origin of our aid-growth model is derived from production functions. In addition, setting the instrumentation strategies we are inspired by a number of works of Ackerberg et al. (2015); Yeoh and Stansel (2013); Bloom et al. (2012); Lee et al. (2005) and Aschauer (1989) who capitalize production technology while investigating economic growth and productivity. More importantly, production function's universal recognition as a fundamental theory of economics and its long history of being capitalized for more than two centuries (Ackerberg et al., 2015) propel us to exploit one of its advanced form- the Cobb-Douglas production function. Moreover, Cobb-Douglas functions' intensity in illustrating 'real-world production processes' makes it a better technology and a credible strategy in econometric estimation process (Besanko and Braeutigam, 2011). Besides, wide ranges of literature suggest that Cobb-Douglas production function is a substantial instrument for linear estimation of various productivity activities (Lee et al., 2005). General framework of Cobb-Douglas production function structured in Besanko and Braeutigam (2011) in the following form:

$$
\mathrm{Q}=\mathrm{AL}^{\alpha} \mathrm{K}^{\beta}
$$

In this framework $Q$ stands for quantity of output derived from $L$ units of labor and $K$ units of capital, and $A, \alpha$, and $\beta$ are positive constants. While, Cobb-Douglas production function's convenience as an augmented neoclassical model encouraged many scholars modifying its original framework. For example, while estimating public expenditures $(G)$ productivity on the economy (Aschauer, 1989) exploits Cobb-Douglas method in the form of:

$$
\mathrm{Y}_{\mathrm{t}}=\mathrm{A}_{\mathrm{t}} * \mathrm{f}\left(\mathrm{N}_{\mathrm{t}}, \mathrm{K}_{\mathrm{t}}, \mathrm{G}_{\mathrm{t}}\right)
$$

Aschauer (1989) add an extra right hand side variable, public expenditure $(\mathrm{G})$ with employment of labor $(\mathrm{N})$, and stock of nonresidential capital (K). Similarly, examine the role of IT on firms' productivity (Bloom et al., 2012) extend original model by employing two more right hand side variables, materials (m) and IT capital (c) in addition to labor (l) and capital (k). Therefore, remodeled Cobb-Douglas production function organized in Bloom et al. (2012) in the way of: 
Alongside, investigating ICT's impact on the economy (Lee et al., 2005) expand Cobb-Douglas model in the form of:

$$
\mathrm{Y}=\mathrm{AICT}^{\beta_{1}} \mathrm{~K}^{\beta_{2}} \mathrm{~L}^{\beta_{3}}
$$

In their approach (Lee et al., 2005) incorporated ICT as a new instrument with existing labor (L) and capital $(\mathrm{K})$. Where $A$ is a constant represents other elements of production, $\beta_{1,} \beta_{2}$, and $\beta_{3}$ are the elasticities of production resources. We follow both Bloom et al. (2012); Lee et al. (2005) and Aschauer (1989)approaches studying the role of foreign aid $(\mathrm{ODA})^{9}$ in economic growth. Therefore, we rewrite Cobb-Douglas production function in the below form:

$$
\mathrm{Y}=\mathrm{AODA}^{\beta_{1}} \mathrm{~K}^{\beta_{2}} \mathrm{~L}^{\beta_{3}}
$$

Where ODA is the net disbursement flows of official development assistance measured as the percentage of GNI, $\mathrm{K}$ is the gross capital formation in terms of percentage of GDP. Due to the inadequacies of labor statistics we proxy labor (L) with population growth (POPLG $)^{10}$. Because, growth of population stimulates productivity in a couple of ways; through supplying additional labor force and create extra demand in the economy (Oxley and Greasley, 1998). Therefore, we argue that economic growth of Bangladesh is the function of foreign aid (ODA), gross capital formation (CAPITAL), and population growth (POPLG). Accordingly, we organize of our aid-growth strategy in the subsequent way:

$$
\mathrm{Y}=\mathrm{AODA}^{\beta_{1}} \mathrm{CAPITAL}^{\beta_{3}} \mathrm{POPLG}^{\beta_{3}}
$$

Finally, for estimation conveniences we capitalize classical (Barro, 1991) cross-country growth regression and structure the above function in the following form:

$$
\mathrm{Y}=\alpha+\beta_{1} \mathrm{ODA}+\beta_{2} \mathrm{CAPITAL}+\beta_{3} \mathrm{POPLG}+\varepsilon
$$

\subsection{The data}

We use annual time series data of World Bank's World Development Indicator (WDI). The data has a span of 42 years ranging from 1973 to 2014, and comprises 4 series including per capita GDP (current prices and in US\$), net ODA received as percentage of gross national income $(\mathrm{GNI})$, gross capital formation as percentage of GDP, and population growth. We rely on this single source because no other institutional sources have comprehensive time series data on Bangladesh for longer period than World Bank has. In addition, we consider that other source resources may not act properly with World Bank data because of different methodologies applied in data collection and processing and which eventually lead to inconsistencies in estimation and analysis ${ }^{11}$.

\section{Estimation Strategies and Empirical Findings}

Setting the estimation strategies we carefully consider following two factors: at first, inability of typical OLS estimation extending standard inferences for policy implications (Deaton, 2010) and the recent surge of time series application (for example, (Nowak-Lehmann et al., 2012; Juselius et al., 2014; Lof et al., 2015; Juselius et al., 2017)) in growth studies. Both reasons prompted us exploiting time series instruments in our empirical strategies. In addition, time series applications' universal acceptance as a superior technology of handling stationary data, motivated us in a great deal (Phillips and Perron, 1988). Generally, time series data are nonstationary in nature and models with nonstationary variables and their statistical significance vastly a debated issue (Wassell and Saunders, 2005). Since, regressions between two or more nonstationary series often produce spurious outcomes; notably, in the form of high coefficient of determination $\left(\mathrm{R}^{2}\right)$, and significant t-statistics even in the absence of sensible correlation (Granger and Newbold, 1974; Phillips and Perron, 1988; Wassell and Saunders, 2005). For this reason, regressions output derived from nonstationary series frequently disqualify for rational policy implications (Wassell and Saunders, 2005).To address this problem, time series techniques initially examine (unit root test) quality (stationarity) of data before using it in empirical investigations.

\subsection{Testing Stationery: The Unit Root Test}

Unit root testis predominantly exploited to identify the stationarity (whether a variable is stationary or nonstationary) of a series (Gujarati, 2004). Major features of stationarity is that when mean and autocovariances of a series does not depend on time then the series is stationary; and in contrast, a series which mean and autocovariances depend on time labeled as nonstationary (Gujarati, 2004). A typical nonstationary series is the random walk can be expressed in the following form:

$$
\mathrm{Y}_{\mathrm{t}}=\rho \mathrm{Y}_{\mathrm{t}-1}+\mathrm{u}_{\mathrm{t}}
$$

In this model $u_{t}$ is a white noise error term. The variance of series $Y$ is changing over time since it depends on the condition of $t$. While random walk is a difference stationary series and the first difference of $\Upsilon$ is stationary and can be written in the form of:

$$
\Delta \mathrm{Y}_{\mathrm{t}}=\delta \mathrm{Y}_{\mathrm{t}-1}+\mathrm{u}_{\mathrm{t}}
$$

Estimating above equation we take null hypothesis $\delta=0$, If $\rho=1$ then $\delta=0$ meaning that series under consideration has a unit root, and the series is not stationary. The notion is that a difference stationary series is integrated and symbolized as $\mathrm{I}(\mathrm{d})$, and $d$ denotes order of integration, the number of unit roots a series contained or the number of difference operations required to make a series stationary. For example, a series has one unit root signified as I(1) series, and a stationary series free of unit root symbolized as I $(0)$ series. In analytical environments several types of unit root test practiced. Among those tests, we utlize a popularly accepted method of an advance option of Dickey-Fuller (DF) test- universally known as augmented Dickey-Fuller (ADF) test (Ng and Perron, 1995).Generally, DF test conducted in three distinct forms considering diverse possibilities, and the options are: random walk process has no drift, random walk process may have drift, and random walk process may have both deterministic and stochastic trends (Gujarati, 2004). While, conducting a DF test, hypothesis is that error term $u_{t}$

${ }^{9}$ We proxy foreign aid as the net disbursement flows of official development assistance (ODA)

${ }^{10}$ Details of the variable descriptions stated in appendix C

${ }^{11}$ According to World Bank (2017). Bangladesh's per capita GDP (current prices) in 2014 is US \$1,086.80. On the contrary, IMF World Economic Outlook April 2017 shows that Bangladesh's per capita GDP (curr 
remains uncorrelated (Gujarati, 2004). However, difficulties surfaced when $u_{i}$ is correlated. To resolve this, Dickey and Fuller (1979) developed a modified version by 'augmenting' all three types of DF test equations and adding a lagged value of dependable variable $\Delta Y_{t}$. However, in this paper we estimate the regressions based on the following two ADF test equations ${ }^{12}$ (Gujarati, 2004):

$$
\begin{gathered}
\Delta \mathrm{Y}_{\mathrm{t}}=\beta_{1}+\delta \mathrm{Y}_{\mathrm{t}-1}+\quad \Delta \mathrm{Y}_{\mathrm{t}-\mathrm{i}}+\varepsilon_{\mathrm{t}} \\
\Delta \mathrm{Y}_{\mathrm{t}}=\beta_{1}+\beta_{2} \mathrm{t}+\delta \mathrm{Y}_{\mathrm{t}-1}+\sum_{\mathrm{i}=1}^{\mathrm{m}} \alpha_{\mathrm{i}} \mathrm{Y}_{\mathrm{t}-\mathrm{i}}+\varepsilon_{\mathrm{t}}
\end{gathered}
$$

Table-1. Augmented Dickey-Fuller (ADF) test output (5\% level of significance)

\begin{tabular}{l|l|l|l|l|l|l}
\hline \multirow{2}{*}{ Variable } & ADF test statistic (t-statistic) & Test critical values (t-statistic) & Prob. \\
\cline { 2 - 7 } & Constant & $\begin{array}{l}\text { Constant, } \\
\text { trend }\end{array}$ & Constant & Constant, trend & Constant & $\begin{array}{l}\text { Constant, } \\
\text { trend }\end{array}$ \\
\hline Level & -2.935001 & -3.523623 & 3.553140 & 1.660312 & 1.0000 & 1.0000 \\
\hline GDP & -2.936942 & -3.540328 & -0.479362 & -2.056948 & 0.8848 & 0.5514 \\
\hline ODA & -2.936942 & -3.526609 & -1.581257 & -3.330771 & 0.4827 & 0.0759 \\
\hline CAPITAL & -2.938987 & -3.529758 & 0.392503 & -2.200237 & 0.9801 & 0.4762 \\
\hline POPLG & \multicolumn{7}{|l}{} \\
\hline First difference \\
\hline $\mathrm{D}$ (GDP) & -2.936942 & -3.526609 & -4.222689 & -5.446197 & 0.0019 & 0.0003 \\
\hline $\mathrm{D}$ (ODA) & -2.936942 & -3.526609 & -9.563917 & -9.593832 & 0.0000 & 0.0000 \\
\hline $\mathrm{D}$ (CAPITAL) & -2.936942 & -3.526609 & -5.269162 & -5.291244 & 0.0001 & 0.0005 \\
\hline $\mathrm{D}$ (POPLG) & -2.938987 & -3.529758 & -9.291159 & -8.351394 & 0.0000 & 0.0000 \\
\hline
\end{tabular}

The ADF test statistic displayed in Table 1, indicate that all four variables are integrated in order of 1 meaning that all four variables are I(1)series. Since, the variables are I(1), therefore, we need to identify the number of cointegrating vectors in the subsequent analytical process (Oxley and Greasley, 1998); (Masih and Masih, 1997). However, conducting remaining tests, we need to determine optimal lag length, at first.

\subsection{Selection of Optimal Lag Order}

Determining optimal lag length we follow Toda and Yamamoto (1995) approach. In doing so, we capitalize usual methods and conduct an unrestricted VAR estimate involving data in levels with automatic 2 lag order. The lag order selection output exhibited in Table 2, and five lag selection criterions (LR, FPE, AIC, SC, HQ) suggest that optimal lag length is 3. For cross checking, we attempt another unrestricted VAR estimation with 4 lag order. Nevertheless, this calculation also recommends same lag length, 3. Since, all the series are integrated in order of $\mathrm{I}(1)$, therefore, following T-Y approach we decide optimal lag order is $4(3+1)$ by adding an extra lag. Consequently, we use 4 lag orders in all the remaining estimations.

Table-2. VAR lag order selection output

\begin{tabular}{l|l|l|l|l|l|l}
\hline Lag & LogL & LR & FPE & AIC & SC & HQ \\
\hline 0 & -375.7156 & NA & 5617.1111 & 19.98503 & 20.15741 & 20.04636 \\
\hline 1 & -177.8088 & 343.7328 & 0.392830 & 10.41099 & 11.27288 & 10.71764 \\
\hline 2 & -139.9454 & 57.79162 & 0.128150 & 9.260282 & 10.81168 & 9.812257 \\
\hline 3 & -98.49156 & $54.54447^{*}$ & $0.036300^{*}$ & $7.920608^{*}$ & $10.16152^{*}$ & $8.717906^{*}$ \\
\hline 4 & -82.76160 & 17.38575 & 0.043093 & 7.934821 & 10.86524 & 8.977441 \\
\hline
\end{tabular}

Source: Authors' calculation

* indicates lag order selected by the criterion

LR: sequential modified LR test statistic (each test at $5 \%$ level)

FPE: Final prediction error

AIC: Akaike information criterion

SC: Schwarz information criterion

HQ: Hannan-Quinn information criterion

\subsection{Testing Cointegration Using Johansen's Methodology}

Analysis of this chapter involves testing cointegration. To move forward, we conduct Johansen $(1991 ; 1995)$ multivariate system of cointegration test to ascertain cointegration relations among the variables. Engle and Granger (1987) are the pioneer of cointegration methodology (Ahmed and Kenji, 2017). However, emergence of Johansen $(1991 ; 1995)$ and Johansen and Juselius (1990) methodologies and their procedural supremacy due to system-based evaluation technologies of cointegration vectors has gained sensible edge over Engle and Granger (1987) theory (Ahmed and Kenji, 2017).While, in a multivariate time series approach with maximum likelihood procedures; Johansen's methodolgy considered as an advanced option (Masih and Masih, 1997). Typically, Johansen methodology is suitable in such an environment where all the variables integrated in order of $\mathrm{I}(1)$ (Österholm and Hjalmarsson, 2007). Since, all variables of our model qualify to this criteria therefore, it would be an appropriate practice to apply Johansen's method. Moreover, within a vector error correction (VEC), framework Johansen's methodology extensively utilized to develop substantial strategies identifying cointegrating relations between the variables (Oxley and Greasley, 1998; Ghosh, 2002). Accordingly, determining cointegration vectors we estimate following equation with order of $\mathrm{p}$ :

$$
\mathrm{y}_{\mathrm{t}}=\mu+\mathrm{A}_{\mathrm{t}} \mathrm{yt}_{\mathrm{t}-1}+\cdots \cdots+\mathrm{A}_{\mathrm{p}} \mathrm{y}_{\mathrm{t}-\mathrm{p}}+\mathrm{B}_{\mathrm{xt}}+\epsilon_{\mathrm{t}}
$$

${ }^{12}$ Equation 16 estimates regression with intercept, while in Equation 17 regressions' estimated with trend and intercept 
In this framework $y_{t}$ is a vector of nonstationary $\mathrm{I}(1)$ variables, $x_{t}$ is a vector of deterministic variables and $\epsilon_{t}$ is a vector of innovations. We can rewrite the equation in the following form also:

$$
\Delta \mathrm{y}_{\mathrm{t}}=\Pi \mathrm{y}_{\mathrm{t}-1}+\sum_{\mathrm{i}=1}^{\mathrm{p}=1} \Gamma_{1} \Delta \mathrm{y}_{\mathrm{t}-\mathrm{i}}+\mathrm{B}_{\mathrm{xt}}+\epsilon_{\mathrm{t}}
$$

Table-3. Johansen cointegration test output (lags interval in first differences: 1 to 4 )

\begin{tabular}{|c|c|c|c|c|c|c|}
\hline \multirow{2}{*}{$\begin{array}{l}\text { Hypothesized } \\
\text { No. of CE(s) }\end{array}$} & \multicolumn{2}{|c|}{ Test statistic } & \multicolumn{2}{|c|}{0.05 critical value } & \multicolumn{2}{|c|}{ Prob.** } \\
\hline & Trace & Max-Eigen & Trace & Max-Eigen & Trace & Max-Eigen \\
\hline \multicolumn{7}{|c|}{ Trend assumption: Linear deterministic trend } \\
\hline None & $119.5347^{*}$ & $61.00638^{*}$ & 47.85613 & 27.58434 & 0.0000 & 0.0000 \\
\hline At most 1 & $58.52829^{*}$ & $38.02562^{*}$ & 29.79707 & 21.13162 & 0.0000 & 0.0001 \\
\hline At most 2 & $20.50268^{*}$ & $16.66634 *$ & 15.49471 & 14.26460 & 0.0081 & 0.0205 \\
\hline At most 3 & 3.836339 & 3.836339 & 3.841466 & 3.841466 & 0.0501 & 0.0501 \\
\hline \multicolumn{7}{|c|}{ Trend assumption: Linear deterministic trend (restricted) } \\
\hline None & $160.7710^{*}$ & $62.71900^{*}$ & 63.87610 & 32.11832 & 0.0000 & 0.0000 \\
\hline At most 1 & $98.05200^{*}$ & $48.77429^{*}$ & 42.91525 & 25.82321 & 0.0000 & 0.0000 \\
\hline At most 2 & $49.27772^{*}$ & $32.61259^{*}$ & 25.87211 & 19.38704 & 0.0000 & 0.0004 \\
\hline At most 3 & $16.66513^{*}$ & $16.66513^{*}$ & 12.51798 & 12.51798 & 0.0096 & 0.0096 \\
\hline
\end{tabular}

Source: Authors' calculation

a. Trace and max-eigen value test indicates 3 cointegrating equations at 0.05 levels under the linear deterministic trend

b. Trace and max-eigen value test indicates 4 cointegrating equations at 0.05 levels under the linear deterministic trend (restricted) *Denotes rejection of hypothesis at 0.05 level

***MacKinnon et al. (1999) p-values

To identify cointegration relationships firstly, we capitalize estimation within linear deterministic trend with 4 lag order to conclude on null hypotheses of 0,1 and 2 cointegration vectors. The output sited in Table 3 indicates that both Trace $(119.5347 ; 58.52829 ; 20.50268)$, and Max-Eigen value (61.00638; 38.02562; 16.66634) statistic are significant at 0.05 critical level, and which confirms existence of 3 cointegrating vectors. Similarly, testing null hypotheses of $0,1,2$ and 3 cointegrating vectors, output of another estimation with 4 lag order and within linear deterministic trend (restricted) find that Trace (160.7710; 98.05200; 49.27772; 16.66513), and Max-Eigen value $(62.71900 ; 48.77429 ; 32.61259 ; 16.66513)$ statistic also remain significant at 0.05 critical level confirming 4 cointegratiing vectors. Thus, existence of multiple cointegrating vectors has been proved through this test.

\subsection{Vector Error Correction Estimate}

In the preceding two tests we examine quality of data. The initial one, ADF test determines that order of integration of all series stand at I(1) confirming the existence of unit roots and more specifically, data will be stationary at first differences. However, major concern is that data in levels suffer significant damage of information linked to their co-movement while making it stationary through first differencing operations (Wahab and Applanaidu, 2015). Subsequent investigation, Johansen maximum likelihood (ML) test of cointegration locates multiple cointegrating vectors and which indicates presence of long-run equilibrium relationship among the variables. Considering such an environment, Engle and Granger (1987) suggest that a vector error correction modeling (VECM) is the appropriate approach instead of a typical VAR estimation to explain the relationships. Therefore, we capitalize (Engle and Granger, 1987) vector error correction framework in the following form to identify causal relationships:

$$
\Delta \mathrm{GDP}_{\mathrm{t}}=\alpha+\Sigma \beta_{1} \Delta \mathrm{GDP}_{\mathrm{t}-\mathrm{n}}+\Sigma \beta_{2} \Delta \mathrm{ODA}_{\mathrm{t}-\mathrm{n}}+\Sigma \beta_{3} \Delta \mathrm{CAPITAL}_{\mathrm{t}-\mathrm{n}}+\Sigma \beta_{4} \Delta \mathrm{POPLG}_{\mathrm{t}-\mathrm{n}}+\lambda \mathrm{ECT}_{\mathrm{t}-\mathrm{n}}+\varepsilon_{\mathrm{t}}
$$

Where $\alpha$ is the constant, $\lambda$ stands for coefficient of error correction term, $E C T_{t-n}$ is the error correction term and $\varepsilon_{t}$ is the white noise error term. In addition, $n$ is the optimal lag length and $\beta_{1}, \beta_{2}, \beta_{s}$ and $\beta_{\star}$ are the coefficients which explain short-run Granger causality of explanatory variables on dependent variable. While coefficient of ECT exploited to determine the long-run equilibrium relationships, and for Granger causality it must be negative and significant (Ahmed and Kenji, 2017).

Table-4. Vector error correction estimates output

\begin{tabular}{l|l|l|l}
\hline \multicolumn{1}{l|}{ Variable } & Coefficient & \multicolumn{1}{l}{ t-statistic } & Prob. \\
\hline \multicolumn{1}{l|}{ Model A: Dependent variable $\Delta \mathrm{GDP}$} & \\
\hline ECT & -0.018332 & -1.654018 & 0.1146 \\
\hline $\mathrm{C}$ & 32.67681 & 1.834772 & 0.0822 \\
\hline$\Delta$ GDPt-1 & 0.192055 & 0.743635 & 0.4662 \\
\hline$\Delta$ GDPt-2 & -0.132601 & -0.603823 & 0.5531 \\
\hline$\Delta$ GDPt-3 & 0.326056 & 1.735313 & 0.0989 \\
\hline$\Delta$ GDPt-4 & -0.021262 & -0.103901 & 0.9183 \\
\hline$\Delta$ ODAt-1 & 0.944205 & 0.114328 & 0.9102 \\
\hline$\Delta$ ODAt-2 & 2.950476 & 0.259035 & 0.7984 \\
\hline$\Delta$ ODAt-3 & 4.675114 & 0.469008 & 0.6444 \\
\hline$\Delta$ ODAt-4 & 0.230430 & 0.032125 & 0.9747 \\
\hline$\Delta$ CAPITALt-1 & -8.834268 & -0.827020 & 0.4185 \\
\hline$\Delta$ CAPITALt-2 & -7.986122 & -0.876074 & 0.3019 \\
\hline$\Delta$ CAPITALt-3 & 2.340438 & 0.306893 & 0.7623 \\
\hline$\Delta$ CAPITALt-4 & 0.218031 & 0.032159 & 0.9747 \\
\hline$\Delta$ POPLGt-1 & 574.9397 & 1.388137 & 0.1812 \\
\hline$\Delta$ POPLGt-2 & -917.3912 & -1.020177 & 0.3205 \\
\hline$\Delta$ POPLGt-3 & 682.4348 & 0.777814 & 0.4463 \\
\hline$\Delta$ POPLGt-4 & -136.3971 & -0.337605 & 0.7394 \\
\hline
\end{tabular}


There are 4 models emerged from the vector error correction estimates (details in appendix, E-2). Out of 4 models we are basically focus on a solo model which is taking GDP as the dependent variable. For analytical convenience, we define this model as model-A. Similarly, we define rest of the three models as model-B (dependent variable $\triangle$ ODA) model-C (dependent variable $\triangle$ CAPITAL), and model-D (dependent variable $\Delta$ POPLG). All coefficients of vector error correction estimates (displayed in Table 4) of model-A found insignificant at 5\% and $10 \%$ significance level stating the nonexistence of short-run or long-run causality among the explanatory variables and GDP growth $(\Delta G D P)$. Since, major purpose of this study is to explain aid-growth nexus therefore; we check four aid coefficients through conducting Wald Test (taking null hypothesis $\Delta \mathrm{ODA}_{\mathrm{t}-1}=\Delta \mathrm{ODA}_{\mathrm{t}-2}=\Delta \mathrm{ODA}_{\mathrm{t}-\mathrm{s}}=$ $\Delta \mathrm{ODA}_{\mathrm{t}-4}=0$ ). Results displayed in Table 5 , and it indicates the absence of short-run causality of aid on GDP growth.

Table-5. Output of Wald Test

\begin{tabular}{l|l|l|l} 
Null Hypothesis: $\Delta \mathrm{ODA}_{\mathrm{t}-1}=\Delta \mathrm{ODA}_{\mathrm{t}-2}=\Delta \mathrm{ODA}_{\mathrm{t}-3}=\Delta \mathrm{ODA}_{\mathrm{t}-4}=0$ & df & Probability \\
\hline Test Statistic & Value & $(4,19)$ & 0.9761 \\
\hline F-statistic & 0.113678 & 4 & 0.9778 \\
\hline Chi-square & 0.454714 & &
\end{tabular}

On the contrary, error correction term (ECT), which is used to examine long-run causality estimated at: coefficient, -0.018332 and probability (prob.) 0.1146 respectively. The ECT also confirms the nonexistence of longrun equilibrium relationships among the dependent and explanatory variables.

\subsection{Vector Error Correction Granger Causality/Block Exogeneity Wald Tests}

Identifying causal relationship we conduct another test- Granger causality/block exogeneity Wald tests using vector error correction framework. The output (details in appendix, F) in Table 6 demonstrates the absence of Granger causality while taking $\Delta \mathrm{GDP}$ as the dependent variable. In contrast, when $\triangle \mathrm{ODA}, \triangle \mathrm{CAPITAL}$, and $\triangle$ POPLG are considered dependent variable we can reject null hypothesis of no causality at $5 \%$ significance level and that confirms the presence of Granger causality. Therefore, this estimation endorses our analytical approach since, it is consistent with one of the important features of the significance of VEC models that cointegrated variables must have causality 'at least one direction either unidirectional or bidirectional' (Granger, 1986; Granger, 1988; Masih and Masih, 1997).

Table-6. Vector error correction Granger Causality/Block Exogeneity Wald Tests output

\begin{tabular}{l|l|l|l|l|l}
\hline Model & Dependent variable & Independent variable & Chi-sq & df & Prob. \\
\hline $\mathrm{A}$ & $\Delta$ GDP & $\Delta$ ODA $\triangle$ CAPITAL $\triangle$ POPLG & 10.42330 & 12 & 0.5789 \\
\hline $\mathrm{B}$ & $\Delta$ ODA & $\Delta$ GDP $\triangle$ CAPITAL $\triangle$ POPLG & 22.25028 & 12 & 0.0348 \\
\hline $\mathrm{C}$ & $\Delta$ CAPITAL & $\Delta$ GDP $\triangle$ ODA $\triangle$ POPLG & 31.27932 & 12 & 0.0018 \\
\hline $\mathrm{D}$ & $\Delta$ POPLG & $\Delta$ GDP $\triangle$ ODA $\triangle$ CAPITAL & 27.84601 & 12 & 0.0058 \\
\hline
\end{tabular}

\subsection{Residual Diagnostic Tests of VECM}

We examine model-A's significance through conducting several residual diagnostic tests (details in appendix, G) and output exhibited in Table 7. At first, we conduct Breusch-Godfrey serial correlation LM test to check serial correlation. Estimated F-statistic and corresponding probability (prob.) reveals that model-A is free of autocorrelation problem. While, three types of heteroskedasticity tests including Breusch-Pagan-Godfrey, Harvey, and $\mathrm{ARCH}$ carried out to identify the heteroskedasticity of time series regression of model-A. All three estimated F-statistic and corresponding probabilities suggest that null hypothesis of no heteroskedasticity is not in a position for rejection. Finally, we conduct histogram normality test of Jarque-Bera to check data distribution status. The Jarque-Bera statistic and corresponding probability (prob.) suggests that data are normally distributed. Therefore, all the residual diagnostic tests confirm the significance of model-A. In addition, model-A's statistical significance also established in other ways particularly, with a good $\mathrm{R}^{2}$ of 0.692773 and a significant prob. (F-statistic) of 0.027249 (appendix, E-2).

Table-7. Summary of residual diagnostic tests

\begin{tabular}{|c|c|c|c|c|c|c|c|c|c|}
\hline \multirow{2}{*}{\multicolumn{2}{|c|}{$\begin{array}{l}\text { Breusch-Godfrey } \\
\text { Serial Correlation } \\
\text { LM Test* }\end{array}$}} & \multicolumn{6}{|c|}{ Heteroskedasticity Test } & \multirow{2}{*}{\multicolumn{2}{|c|}{$\begin{array}{l}\text { Histogram- Normality } \\
\text { Test }\end{array}$}} \\
\hline & & \multicolumn{2}{|c|}{$\begin{array}{l}\text { Breusch-Pagan- } \\
\text { Godfrey }\end{array}$} & \multicolumn{2}{|l|}{ Harvey } & \multicolumn{2}{|l|}{ ARCH*** } & & \\
\hline $\begin{array}{l}\mathrm{F}- \\
\text { statistic }\end{array}$ & $\begin{array}{l}\text { Prob. (4, } \\
15)\end{array}$ & F-statistc & $\begin{array}{l}\text { Prob. F (20, } \\
16)\end{array}$ & F-statistc & $\begin{array}{l}\text { Prob. F } \\
(20,16)\end{array}$ & $\begin{array}{l}\mathrm{F}- \\
\text { statistc }\end{array}$ & $\begin{array}{l}\text { Prob. F } \\
(20,16)\end{array}$ & $\begin{array}{l}\text { Jarque- } \\
\text { Bera }\end{array}$ & $\begin{array}{l}\text { Probabilit } \\
\mathrm{y}\end{array}$ \\
\hline \multicolumn{10}{|c|}{ Model: Dependent variable $\Delta \mathrm{GDP}$} \\
\hline 0.926414 & 0.4746 & 1.047583 & 0.4686 & 1.661351 & 0.1532 & 0.843695 & 0.5094 & 0.846931 & 0.654774 \\
\hline
\end{tabular}

Source: Authors' calculation

* Lag to include 4

**Number of lag 4

\section{Conclusions}

We endeavor to answer few crucial issues raised at the prevailing aid-growth literature including model specification, instrumentation, and estimation strategies. Firstly, we address the issue of model specification proposing an aid-growth approach exploiting both neoclassical cross-country growth model (Barro, 1991) and Cobb-Douglas production technology. In relation to instrumentation strategies, we intensely survey 'conditional growth studies' where it is argued that aid effectiveness depends on good macroeconomic, trade, political, and environmental policies. However, we simply rely on conventional macroeconomic statistic instead of incorporating policy variables; since, highly rated (Rajan and Subramanian, 2008) remain unsuccessful finding any significance of development assistances while incorporating policy variables with conventional macroeconomic variables following 
four major 'conditional aid-growth studies' ${ }^{13}$. We consider this will act to get back the aid-growth debate on the right track. In the next, we address the concerns of Deaton (2010) and Rajan and Subramanian (2008) regarding the inability of typical cross-country OLS estimations to get rid of the 'spurious regressions' problem due to the existence of noise in the data. We adopt country-specific approach by taking the case of a leading aid-recipient country. Our estimation strategies equipped with error correction techniques which are able keeping the outcomes free of 'spurious regressions' problem. Capitalizing vector error correction modeling and Granger causality test within the vector error correction framework, we do not find any short-run or long-run causality of development assistance on real GDP growth. Therefore, our findings strongly support (Rajan and Subramanian, 2008) and reject the conclusions of so-called 'conditional growth studies'. We consider this study has great policy implications since; core development planning of LDCs still depends on the size of ODA. Given this context, country's like Bangladesh who aspires rapid economic development need to redefine major growth strategies and to revisit existing approaches regarding ODA financed development programs.

\section{References}

Ackerberg, D.A., K. Caves and G. Frazer, 2015. Identification properties of recent production function estimators. Econometrica, 83(6): 2411-2451. View at Google Scholar | View at Publisher

Ahmed, K.Y. and Y. Kenji, 2017. Source of economic growth in Ethiopia: An application of vector error correction model. Australian Academy of Business and Economics Review, 2(4): 285-292. View at Google Scholar

Alesina, A. and D. Dollar, 2000. Who gives foreign aid to whom and why? Journal of Economic Growth, 5(1): 33-63. View at Google Scholar

Aschauer, D.A., 1989. Is public expenditure productive? Journal of Monetary Economics, 23(2): 177-200. View at Google Scholar

Barro, R.J., 1991. Economic growth in a cross section of countries. Quarterly Journal of Economics, 106(2): 407-443. View at Google Scholar | View at Publisher

Besanko, D.A. and R.R. Braeutigam, 2011. Macroeconomics. 4th Edn., Hoboken, NJ 07030-5774, USA: John Wiley \& Sons Inc. 111 River Street.

Bloom, N., R. Sadun and J. Van Reenen, 2012. Americans do IT better: US multinationals and the productivity miracle. American Economic Review, 102(1): 167-201. View at Google Scholar | View at Publisher

Boone, P., 1996. Politics and the effectiveness of foreign aid. European Economic Review, 4O(2): 289-329. View at Google Scholar

Bourguignon, F. and M. Sundberg, 2007. Aid effectiveness: Opening the black box. American Economic Review, 97(2): $316-321$. View at Google Scholar | View at Publisher

Burnside, A.C. and D.D. David, 2000. Aid, policies, and growth. American Economic Review, 90(4): 847-868. View at Google Scholar

Chenery, H.B., 1966. Foreign assistance and economic development. In capital movements and economic development. UK: Palgrave Macmillan. pp: 268-292.

Clemens, M.A., S. Radelet and R.R. Bhavnani, 2004. Counting chickens when they hatch: The short term effect of aid on growth. Retrieved from http://econwpa.repec.org/eps/if/papers/0407/0407010.pdf.

Collier, P. and D. Dollar, 2002. Aid allocation and poverty reduction. European Economic Review, 46(8): 1475-1500. View at Google Scholar $\mid$ View at Publisher

Dalgaard, C.J. and H. Hansen, 2001. On aid, growth and good policies. Journal of Development Studies, 37(6): 17-41. View at Google Scholar | View

Dalgaard, C.J., H. Hansen and F. Tarp, 2004. On the empirics of foreign aid and growth. Economic Journal, 114(496): F 191-F2 16. View at Google Scholar | View at Publisher

Deaton, A., 2010. Instruments, randomization, and learning about development. Journal of Economic Literature, 48(2): 424-455. View at Google Scholar $\mid$ View at Publisher

Dickey, D.A. and W.A. Fuller, 1979. Distribution of the estimators for autoregressive time series with a unit root. Journal of the American Statistical Association, 74(366a): 427-431. View at Google Scholar | View at Publisher

Dollar, D. and A. Kraay, 2002. Growth is good for the poor. Journal of Economic Growth, 7(3): 195-225. View at Google Scholar

Doppelhofer, G., R.I. Miller and X. Sala-i-Martin, 2000. Determinants of long-term growth: A Bayesian averaging of classical estimates (BACE) approach (No. w7750), National Bureau of Economic Research.

Doucouliagos, H. and M. Paldam, 2009. The aid effectiveness literature: The sad results of 40 years of research. Journal of Economic Surveys, 23(3): 433-461. View at Google Scholar | View at Publisher

Easterly, W., 2003. Can foreign aid buy growth? Journal of Economic Perspectives, 17(3): 23-48. View at Google Scholar |View at Publisher

Easterly, W., R. Levine and D. Roodman, 2003. New data, new doubts: A comment on burnside and Dollar's" aid, policies, and growth" (2000) (No. w9846). National Bureau of Economic Research. Retrieved from http://faculty.haas.berkeley.edu/ross_levine/papers/Forth_Comment_New\%20Data\%20New\%20Doubt.pdf.

Easterly, W., R. Levine and D. Roodman, 2004. Aid, policies, and growth: Comment. American Economic Review, 94(3): 774-780. View at Google Scholar

Engle, R.F. and C.W. Granger, 1987. Co-integration and error correction: Representation, estimation, and testing. Econometrica: Journal of the Econometric Society, 55(2): 25 1-276. View at Google Scholar | View at Publisher

Galiani, S., S. Knack, L.C. Xu and B. Zou, 2014. The effect of aid on growth: Evidence from a quasi-experiment. Journal of Economic Growth, 22(1): 1-33.

Ghosh, S., 2002. Electricity consumption and economic growth in India. Energy Policy, 30(2): 125-129. View at Google Scholar | View at Publisher

Granger, C.W., 1986. Developments in the study of cointegrated economic variables. Oxford Bulletin of Economics and Statistics, 48(3): 213-228. View at Google Scholar | View at Publisher

Granger, C.W., 1988. Some recent development in a concept of causality. Journal of Econometrics, 39(1-2): 199-211. View at Google Scholar | View at Publisher

Granger, C.W. and P. Newbold, 1974. Spurious regressions in econometrics. Journal of Econometrics, 2(2): 11 1-120. View at Google Scholar | View at Publisher

Griffin, K., 1978. Foreign capital, domestic savings and economic development. In International Inequality and National Poverty. UK: Palgrave Macmillan. pp: 57-80.

Griffin, K.B. and J.L. Enos, 1970. Foreign assistance: Objectives and consequences. Economic Development and Cultural Change, 18(3): $313-$ 327. View at Google Scholar | View at Publisher

Guillaumont, P. and L. Chauvet, 2001. Aid and performance: A reassessment. Journal of Development Studies, 37(6): 66-92. View at Google Scholar |View at Publisher

Gujarati, D., 2004. Basic econometrics. United States Military Academy, West Point.

Gulati, U.C., 1978. Effect of capital imports on savings and growth in less developed countries. Economic Inquiry, 16(4): 563-569. View at Google Scholar | View at Publisher

Hansen, H. and F. Tarp, 2000. Aid effectiveness disputed. Foreign Aid and Development: Lessons Learnt and Directions for the Future: 103128. View at Google Scholar

Hansen, H. and F. Tarp, 2001. Aid and growth regressions. Journal of Development Economics, 64(2): 547-570. View at Google Scholar | View at

Publisher
Hendry, D.F. and H.M. Krolzig, 2004. We ran one regression. Oxford Bulletin of Economics and Statistics, 66(5): 799-810. View at Google Scholar | View at Publisher

International Monetary Fund (IMF), 2017. World economic outlook database April 2017. [Accessed 2017 May 30].

Johansen, S., 1991. Estimation and hypothesis testing of cointegration vectors in Gaussian vector autoregressive models. Econometrica: Journal of the Econometric Society, 59(6): 1551-1580. View at Google Scholar | View at Publisher

${ }^{13}$ The studies are: Burnside and David (2000). Hansen and Tarp (2001). Collier and Dollar (2002). and Dalgaard, Hansen and Tarp (2004). 
Johansen, S., 1995. Likelihood-based inference in cointegrated vector autoregressive models. Oxford University Press on Demand. Retrieved from http://econpapers.repec.org/bookchap/oxpobooks/9780198774501.htm.

Johansen, S. and K. Juselius, 1990. Maximum likelihood estimation and inference on cointegration-with applications to the demand for money. Oxford Bulletin of Economics and Statistics, 52(2): 169-2 10. View at Google Scholar | View at Publisher

Juselius, K., N.F. Møller and F. Tarp, 2014. The long-run impact of foreign aid in 36 African countries: Insights from multivariate time series analysis. Oxford Bulletin of Economics and Statistics, 76(2): 153-184. View at Google Scholar $\mid$ View at Publisher

Juselius, K., A. Reshid and F. Tarp, 2017. The real exchange rate, foreign aid and macroeconomic transmission mechanisms in Tanzania and Ghana. Journal of Development Studies: 1-29. View at Google Scholar

Lee, S.Y.T., R. Gholami and T.Y. Tong, 2005. Time series analysis in the assessment of ICT impact at the aggregate level-lessons and implications for the new economy. Information \& Management, 42(7): 1009-1022. View at Google Scholar | View at Publisher

Lensink, R. and H. White, 2001. Are there negative returns to aid? Journal of Development Studies, 37(6): 42-65. View at Google Scholar

Lof, M., T.J. Mekasha and F. Tarp, 2015. Aid and income: Another time-series perspective. World Development, 69: 19-30. View at Google Scholar | View at Publisher

MacKinnon, J.G., A.A. Haug and L. Michelis, 1999. Numerical distribution functions of likelihood ratio tests for cointegration. Journal of Applied Econometrics, 14(5): 563-577. View at Google Scholar | View at Publisher

Masih, A.M. and R. Masih, 1997. On the temporal causal relationship between energy consumption, real income, and prices: Some new evidence from Asian-energy dependent NICs based on a multivariate cointegration/vector error-correction approach. Journal of Policy Modeling, 19(4): 417-440. View at Google Scholar | View at Publisher

Mosley, P., 1980. Aid, savings and growth revisited. Oxford Bulletin of Economics and Statistics, 42(2): 79-95. View at Google Scholar | View at Publisher

Mosley, P., 1986. Aid-effectiveness: The micro-macro paradox. Ids Bulletin, 17(2): 22-27. View at Google Scholar | View at Publisher

Mosley, P., 1987. Foreign aid, its defense and reform. University Press of Kentucky.

Mosley, P., J. Hudson and S. Horrell, 1987. Aid, the public sector and the market in less developed countries. Economic Journal, 97(387): 616-641. View at Google Scholar | View at Publisher

$\mathrm{Ng}, \mathrm{S}$. and P. Perron, 1995. Unit root tests in ARMA models with data-dependent methods for the selection of the truncation lag. Journal of the American Statistical Association, 90(429): 268-281. View at Google Scholar |View at Publisher

Nowak-Lehmann, F., A. Dreher, D. Herzer, S. Klasen and I. Martínez-Zarzoso, 2012. Does foreign aid really raise per capita income? A time series perspective. Canadian Journal of Economics/Revue Canadienned'Economique, 45(1): 288-313. View at Google Scholar | View at Publisher

Österholm, P. and E. Hjalmarsson, 2007. Testing for cointegration using the Johansen methodology when variables are near-integrated (No. 7-141). International Monetary $\quad$ Fund. Retrieved https://pdfs.semanticscholar.org/d92d/8befod79236c2cob9684a3a35e2a69efo615.pdf.

Oxley, L. and D. Greasley, 1998. Vector autoregression, cointegration and causality: Testing for causes of the British industrial revolution. Applied Economics, 30(10): 1387-1397. View at Google Scholar |View at Publisher

Papanek, G.F., 1972. The effect of aid and other resource transfers on savings and growth in less developed countries. Economic Journal, 82(327): 934-950. View at Google Scholar | View at Publisher

Papanek, G.F., 1973. Aid, foreign private investment, savings, and growth in less developed countries. Journal of Political Economy, 81(1): 120-130. View at Google Scholar | View at Publisher

Phillips, P.C. and P. Perron, 1988. Testing for a unit root in time series regression. Biometrika: 335-346. View at Google Scholar |View at Publisher

Rajan, R.G. and A. Subramanian, 2008. Aid and growth: What does the cross-country evidence really show? Review of Economics and Statistics, 90(4): 643-665. View at Google Scholar | View at Publisher

Roodman, D., 2007. The anarchy of numbers: Aid, development, and cross-country empirics. World Bank Economic Review, $21(2)$ : $255-277$. View at Google Scholar | View at Publisher

Rosenstein-Rodan, P.N., 1961. International aid for underdeveloped countries. Review of Economics and Statistics, 43(2): 107-138. View at Google Scholar

Sala-i-Martin, X.X., 1997a. I just ran two million regressions. American Economic Review, 87(2): 178-183.

Sala-i-Martin, X.X., 1997b. I just ran four million regressions (No. w6252). National Bureau of Economic Research. Retrieved from http://ibradford-delong.net/teaching_folder/Econ_202c/readberk/4-Patterns_of_Growth/Sala-i-Martin_4M.pdf.

Toda, H.Y. and T. Yamamoto, 1995. Statistical inference in vector autoregressions with possibly integrated processes. Journal of Econometrics, 66(1): 225-250. View at Google Scholar | View at Publisher

Wahab, N.T.A. and S.D. Applanaidu, 2015. An econometric analysis of food security determinants in Malaysia: A vector error correction model approach (VECM). Asian Social Science, 11(23): 1-11. View at Google Scholar | View at Publisher

Wassell, C.S. and P.J. Saunders, 2005. Time series evidence on social security and private saving: The issue revisited. Ellen sburg: Department of Economics, Central Washington University.

Weisskopf, T.E., 1972. The impact of foreign capital inflow on domestic savings in underdeveloped countries. Journal of International Economics, 2(1): 25-38. View at Google Scholar | View at Publisher

World Bank, 2017. World development indicators. Retrieved from http://databank.worldbank.org/data/reports.aspx?source=worlddevelopment-indicators [Accessed 2017 May 30].

Yeoh, M. and D. Stansel, 2013. Is public expenditure productive: Evidence from the manufacturing sector in US cities, 1880-1920. Cato Journal, 33(1): 1-28. View at Google Scholar

\section{Appendix A: Abbreviations}

ADF test: Augmented Dickey-Fuller test

AEL: Aid effectiveness literature

AIC: Akaike information criterion

ECT: Error correction term

FPE: Final prediction error

GDP: Gross domestic product

GNI: Gross national income

HQ: Hannan-Quinn information criterion

IMF: International Monetary Fund

LDC: Less developed country

LDCs: Less developed countries

ODA: Official development assistance

OLS: Ordinary least squares

SC: Schwarz information criterion

T-Y: Toda and Yamamoto

WDI: World development indicators

WEO: World economic outlook

WW2: World War Two

VAR: Vector auto regression

VECM: Vector error correction modeling 
Appendix B: The Data

\begin{tabular}{|c|c|c|c|c|}
\hline Year & $\begin{array}{l}\text { GDP per capita in } \\
\text { US } \$(G D P)\end{array}$ & $\begin{array}{l}\text { ODA(percent } \\
\text { of GNI) }\end{array}$ & $\begin{array}{l}\text { Gross capital } \\
\text { formation (percent of } \\
\text { GDP) (CAPITAL) }\end{array}$ & $\begin{array}{l}\text { Population growth } \\
\text { (POPLG) }\end{array}$ \\
\hline 1973 & 117.7819065 & 5.198165 & 8.712006898 & 1.585485524 \\
\hline 1974 & 179.1641755 & 4.243359853 & 7.374857223 & 1.703316829 \\
\hline 1975 & 272.9701785 & 5.512471456 & 6.147905815 & 1.997715897 \\
\hline 1976 & 138.7232244 & 4.927019983 & 9.911362042 & 2.334804116 \\
\hline 1977 & 128.942513 & 8.162886773 & 11.5232178 & 2.596271472 \\
\hline 1978 & 172.6062003 & 7.5161892 & 11.54679855 & 2.766916511 \\
\hline 1979 & 196.6780059 & 7.48378619 & 11.20387213 & 2.810825619 \\
\hline 1980 & 222.9242646 & 7.08665606 & 14.4393913 & 2.769204023 \\
\hline 1981 & 242.2224312 & 5.337540043 & 17.15576644 & 2.710344222 \\
\hline 1982 & 215.7421858 & 7.096030945 & 17.36327909 & 2.677536855 \\
\hline 1983 & 199.6916194 & 5.751979043 & 16.56273677 & 2.658002448 \\
\hline 1984 & 208.9325984 & 6.100986381 & 16.48425757 & 2.661362183 \\
\hline 1985 & 239.5138363 & 4.972468716 & 15.8309437 & 2.675519221 \\
\hline 1986 & 227.8791364 & 6.432029907 & 16.17645483 & 2.689529516 \\
\hline 1987 & 247.5620475 & 7.208769256 & 15.47344203 & 2.683137929 \\
\hline 1988 & 263.7341157 & 5.938576105 & 15.73598307 & 2.64460664 \\
\hline 1989 & 278.3516037 & 6.116851021 & 16.12091443 & 2.567501631 \\
\hline 1990 & 298.144992 & 6.492388153 & 16.45867552 & 2.466950281 \\
\hline 1991 & 285.296976 & 5.946636189 & 16.89594746 & 2.355938926 \\
\hline 1992 & 285.6978098 & 5.598726634 & 17.30502928 & 2.257783657 \\
\hline 1993 & 292.3645263 & 4.060145962 & 17.94683201 & 2.187760068 \\
\hline 1994 & 291.3258679 & 5.004785042 & 18.40255619 & 2.155122135 \\
\hline 1995 & 320.3619277 & 3.27837883 & 19.11979582 & 2.1457187 \\
\hline 1996 & 383.8299551 & 2.577291706 & 20.7299506 & 2.138090473 \\
\hline 1997 & 390.4079054 & 2.04049926 & 21.81621451 & 2.115690607 \\
\hline 1998 & 396.1696495 & 2.26168444 & 22.12141282 & 2.078586608 \\
\hline 1999 & 398.2295463 & 2.307716612 & 22.7213703 & 2.021669268 \\
\hline 2000 & 406.5317405 & 2.128498674 & 23.80856257 & 1.94944844 \\
\hline 2001 & 403.5945462 & 1.876225243 & 24.17430673 & 1.882916186 \\
\hline 2002 & 401.7081533 & 1.592481356 & 24.34141614 & 1.816606212 \\
\hline 2003 & 434.0465632 & 2.228824518 & 24.67918886 & 1.726004223 \\
\hline 2004 & 462.2748798 & 2.08147327 & 24.99183394 & 1.605803333 \\
\hline 2005 & 485.8528881 & 1.818585047 & 25.83043551 & 1.47034775 \\
\hline 2006 & 495.8537802 & 1.609564116 & 26.14414575 & 1.326957091 \\
\hline 2007 & 543.0822631 & 1.788530336 & 26.17849707 & 1.203348026 \\
\hline 2008 & 618.0758836 & 2.098240471 & 26.2022714 & 1.125881485 \\
\hline 2009 & 683.6144223 & 1.108309467 & 26.20605702 & 1.109061795 \\
\hline 2010 & 760.3319352 & 1.126595014 & 26.24665618 & 1.134879634 \\
\hline 2011 & 838.5478017 & 1.074870504 & 27.42097337 & 1.172933905 \\
\hline 2012 & 858.9333626 & 1.485229114 & 28.26233501 & 1.199882864 \\
\hline 2013 & 954.3963997 & 1.622223223 & 28.38962075 & 1.216351172 \\
\hline 2014 & 1086.800087 & 1.31122154 & 28.57787571 & 1.214377385 \\
\hline
\end{tabular}

Source: World Bank World Development Indicators 2017

\section{Appendix C: Data Description}

\begin{tabular}{l|l}
\hline Variable & Description \\
\hline GDP & $\begin{array}{l}\text { GDP per capita is gross domestic product (current prices in US \$) divided by } \\
\text { midyear population. }\end{array}$ \\
\hline ODA & $\begin{array}{l}\text { Net official development assistance (ODA) consists of disbursements of loans made } \\
\text { on concessional terms and grants by official agencies of the members of the } \\
\text { Development Assistance Committee (DAC), multilateral institutions, and non-DAC } \\
\text { countries to promote economic development and welfare in countries and territories } \\
\text { in the DAC list of ODA recipients, expressed at percentage of gross national income } \\
\text { (GNI). }\end{array}$ \\
\hline Capital (CAPITAL) & $\begin{array}{l}\text { Capital is the gross capital formation expressed in percentage of GDP consists of } \\
\text { outlays on additions to the fixed assets of the economy plus net changes in the level } \\
\text { of inventories. }\end{array}$ \\
\hline Population (POPLG) & $\begin{array}{l}\text { Annual population growth rate for year t is the exponential rate of growth of } \\
\text { midyear population from year t-1 to t, expressed as a percentage. }\end{array}$ \\
\hline Source: World Bank World Development Indicators 2017
\end{tabular}




\section{Appendix D: Johansen Cointegration Test}

Date: 06/04/17 Time: 9:49

Sample (adjusted): 19782014

Included obervations: 37 after adjustments

Trend assumption: Linear deterministic trend (restricted)

Series: GDP ODP CAPTIAL POPLG

Lags interval (in first differences): 1 to 4

Unrestricted Cointegration Rank Test (Trace)

\begin{tabular}{l|l|l|l|l}
\hline Hypothesized No. of CE(s) & Elgenvalue & Trace statistic & 0.05 Critical Value & Prob.** \\
\hline None $*$ & 0.807724 & 119.5347 & 47.85613 & 0.0000 \\
\hline At most 1* & 0.642178 & 58.52829 & 29.79707 & 0.0000 \\
\hline At most $*^{*}$ & 0.362653 & 20.50268 & 15.49471 & 0.0081 \\
\hline At most ${ }^{*}$ & 0.098491 & 3.836339 & 3.841466 & 0.0501 \\
\hline Tra ti
\end{tabular}

0.098491

3.836339

0.0501

* denotes rejection of the hypothesis at the 0.05 level

***MacKinnon et al. (1999) p-value

Unrestricted Cointegration Rank Test (Maximum Eigenvalue)

\begin{tabular}{l|l|l|l|l}
\hline Hypothesized No. of CE(s) & Elgenvalue & $\begin{array}{l}\text { Max-Eigen } \\
\text { Statistic }\end{array}$ & 0.05 Critical Value & Prob.** \\
\hline None $*$ & 0.807724 & 61.00638 & 27.58434 & 0.0000 \\
\hline At most $*^{*}$ & 0.642178 & 38.02562 & 21.13162 & 0.0001 \\
\hline At most 2* & 0.362653 & 16.66634 & 14.26460 & 0.0205 \\
\hline At most ${ }^{*}$ & 0.098491 & 3.836339 & 3.841466 & 0.0501 \\
\hline Hat
\end{tabular}

Max-eigenvalue test indicates 3 cointegrating eqn (s) at the 0.05 level

* denotes rejection of the hypothesis at the 0.05 level

***MacKinnon et al. (1999) p-value

Date: 06/04/17 Time: 10:03

Sample (adjusted): 19782014

Included obervations: 37 after adjustments

Trend assumption: Linear deterministic trend (restricted)

Series: GDP ODP CAPTIAL POPLG

Lags interval (in first differences): 1 to 4

Unrestricted Cointegration Rank Test (Trace)

\begin{tabular}{|c|c|c|c|c|}
\hline Hypothesized No. of CE(s) & Elgenvalue & Trace statistic & 0.05 Critical Value & Prob.*** \\
\hline None ${ }^{*}$ & 0.816421 & 160.87610 & 63.87610 & 0.0000 \\
\hline At most $1^{*}$ & 0.732390 & 42.91525 & 42.91525 & 0.0000 \\
\hline At most $2^{*}$ & 0.585806 & 25.87211 & 25.87211 & 0.0000 \\
\hline At most $3^{*}$ & 0.362633 & 12.51798 & 12.51798 & 0.0096 \\
\hline \multicolumn{5}{|c|}{$\begin{array}{l}\text { Trace test indicates } 4 \text { cointegrating eqn }(\mathrm{s}) \text { at the } 0.05 \text { level } \\
\text { * denotes rejection of the hypothesis at the } 0.05 \text { level } \\
\text { ***ackinnon et al. (1999) p-value }\end{array}$} \\
\hline \multicolumn{5}{|c|}{ Unrestricted Cointegration Rank Test (Maximum Eigenvalue) } \\
\hline Hypothesized No. of CE(s) & Elgenvalue & Max-Eigen Statistic & 0.05 Critical Value & Prob.*** \\
\hline None $*$ & 0.816421 & 62.71900 & 32.11832 & 0.0000 \\
\hline At most $1^{*}$ & 0.732390 & 48.77429 & 25.82321 & 0.0000 \\
\hline At most $2^{*}$ & 0.585806 & 32.61259 & 19.38704 & 0.0000 \\
\hline At most $3^{*}$ & 0.362633 & 16.66513 & 12.51798 & 0.0096 \\
\hline
\end{tabular}

\section{Appendix E}

\section{Vector Error Correction Estimates}

Date: 04/06/17 Time: 14:15

Sample (adjusted): 1978-2014

Included observations: 37 after adjustments

Standard errors in ( ) \& t-statistics in [

\begin{tabular}{|c|c|c|c|c|}
\hline CointegratingEq: & CointEq1 & & & \\
\hline $\operatorname{GDP}(-1)$ & 1.000000 & & & \\
\hline ODA $(-1)$ & $\begin{array}{l}124.4875 \\
(154.249) \\
{[0.80705)}\end{array}$ & & & \\
\hline CAPITAL $(-1)$ & $\begin{array}{l}92.06700 \\
(78.0954) \\
{[1.17890]}\end{array}$ & & & \\
\hline POPULATION (-1) & $\begin{array}{l}2489.280 \\
(408.444) \\
{[6.09454]}\end{array}$ & & & \\
\hline $\mathrm{C}$ & -7928.584 & & & \\
\hline Error Correction & $\mathrm{D}(\mathrm{GDP})$ & $\mathrm{D}(\mathrm{ODA})$ & D (CAPITAL) & D (POPLG) \\
\hline CointEq 1 & $\begin{array}{l}-0.018332 \\
(0.01108) \\
{[-1.65402]}\end{array}$ & $\begin{array}{l}-0.000722 \\
(0.00029) \\
{[-2.50244]}\end{array}$ & $\begin{array}{l}-0.000296 \\
(0.00023) \\
{[-1.31052]}\end{array}$ & $\begin{array}{l}-5.76 \mathrm{E}-07 \\
(5.1 \mathrm{E}-06) \\
{[-0.11193]}\end{array}$ \\
\hline
\end{tabular}




\begin{tabular}{|c|c|c|c|c|}
\hline $\mathrm{D}(\mathrm{GDP}(-1))$ & $\begin{array}{l}0.192055 \\
(0.25827) \\
{[0.74363]}\end{array}$ & $\begin{array}{l}-0.010328 \\
(0.00673) \\
{[-1.53548]}\end{array}$ & $\begin{array}{l}0.005085 \\
(0.00527) \\
{[0.96510]} \\
\end{array}$ & $\begin{array}{l}-4.77 \mathrm{E}-05 \\
(0.00012) \\
{[-0.39738]}\end{array}$ \\
\hline $\mathrm{D}(\mathrm{GDP}(-2))$ & $\begin{array}{l}-0.132601 \\
(0.21960) \\
{[-0.60382]}\end{array}$ & $\begin{array}{l}-0.003558 \\
(0.00572) \\
{[-0.62202]}\end{array}$ & $\begin{array}{l}-0.005496 \\
(0.00448) \\
{[-1.22676]}\end{array}$ & $\begin{array}{l}-2.01 \mathrm{E}-06 \\
(0.00010) \\
{[-0.19708]}\end{array}$ \\
\hline $\mathrm{D}(\mathrm{GDP}(-3))$ & $\begin{array}{l}0.326056 \\
(0.18789) \\
{[1.73531]}\end{array}$ & $\begin{array}{l}-0.006538 \\
(0.00489) \\
{[-1.33610]}\end{array}$ & $\begin{array}{l}0.003398 \\
(0.00383) \\
{[0.88644]}\end{array}$ & $\begin{array}{l}0.000121 \\
(8.7 \mathrm{E}-05) \\
{[1.38744]}\end{array}$ \\
\hline $\mathrm{D}(\mathrm{GDP}(-4))$ & $\begin{array}{l}-0.021262 \\
(0.20464) \\
{[-0.10390]}\end{array}$ & $\begin{array}{l}0.011214 \\
(0.00533) \\
{[2.10410]}\end{array}$ & $\begin{array}{l}-0.008723 \\
(0.00417) \\
{[-2.08938]}\end{array}$ & $\begin{array}{l}-3.52 \mathrm{E}-05 \\
(9.5 \mathrm{E}-05) \\
{[-0.36988]}\end{array}$ \\
\hline $\mathrm{D}(\mathrm{ODA}(-1))$ & $\begin{array}{l}0.944206 \\
(8.25877) \\
{[0.11433]}\end{array}$ & $\begin{array}{l}-0.819793 \\
(0.21510) \\
{[-3.81128]}\end{array}$ & $\begin{array}{l}-0.237344 \\
(0.16848) \\
{[-1.40873]}\end{array}$ & $\begin{array}{l}0.001366 \\
(0.00384) \\
{[0.35597]}\end{array}$ \\
\hline $\mathrm{D}(\mathrm{ODA}(-2))$ & $\begin{array}{l}2.950476 \\
(11.3903) \\
{[0.25904]}\end{array}$ & $\begin{array}{l}-0.818083 \\
(0.29666) \\
{[-275769]}\end{array}$ & $\begin{array}{l}-0.163204 \\
(0.23236) \\
{[0.70237]}\end{array}$ & $\begin{array}{l}0.005637 \\
(0.00529) \\
{[1.065081]}\end{array}$ \\
\hline $\mathrm{D}(\mathrm{ODA}(-3))$ & $\begin{array}{l}4.675114 \\
(9.96808) \\
{[0.46901]}\end{array}$ & $\begin{array}{l}-0.606285 \\
(0.25962) \\
{[-2.33532]}\end{array}$ & $\begin{array}{l}-0.204697 \\
(0.20335) \\
{[-1.00662]}\end{array}$ & $\begin{array}{l}0.003029 \\
(0.00463) \\
{[0.65406]}\end{array}$ \\
\hline $\mathrm{D}(\mathrm{ODA}(-4))$ & $\begin{array}{l}0.230430 \\
(7.17290) \\
{[0.03213]}\end{array}$ & $\begin{array}{l}-0.351906 \\
(0.18682) \\
{[-1.88371]}\end{array}$ & $\begin{array}{l}-0.038276 \\
(0.14633)[- \\
{[0.026157]}\end{array}$ & $\begin{array}{l}0.002578 \\
(0.00333) \\
{[0.77349]}\end{array}$ \\
\hline D (CAPITAL $(-1))$ & $\begin{array}{l}-8.834268 \\
(10.6821) \\
{[-0.82702}\end{array}$ & $\begin{array}{l}-0.717825 \\
(0.27821) \\
{[-2.58015]}\end{array}$ & $\begin{array}{l}0.350906 \\
(0.21792) \\
{[1.61028]}\end{array}$ & $\begin{array}{l}0.004207 \\
(0.00496) \\
{[0.84761]}\end{array}$ \\
\hline D (CAPITAL $(-2))$ & $\begin{array}{l}-7.986122 \\
(9.11581) \\
{[-0.87607]}\end{array}$ & $\begin{array}{l}-0.214859 \\
(0.23742) \\
{[-0.90498]}\end{array}$ & $\begin{array}{l}-0.358030 \\
(0.18596) \\
{[-1.92526]}\end{array}$ & $\begin{array}{l}0.004375 \\
(0.00424) \\
{[1.03290]}\end{array}$ \\
\hline D (CAPITAL(-3)) & $\begin{array}{l}2.340438 \\
(7.62624) \\
{[0.30689]}\end{array}$ & $\begin{array}{l}-0.557906 \\
(0.19862) \\
{[-2.80887]}\end{array}$ & $\begin{array}{l}0.076628 \\
(0.15558) \\
{[0.49254]}\end{array}$ & $\begin{array}{l}-0.005680 \\
(0.00354) \\
{[-1.60306]}\end{array}$ \\
\hline $\mathrm{D}(\mathrm{CAPITAL}(-4))$ & $\begin{array}{l}0.218031 \\
(6.77971) \\
{[0.03216]}\end{array}$ & $\begin{array}{l}-0.333128 \\
(0.17658) \\
{[-1.88661]}\end{array}$ & $\begin{array}{l}-0.006779 \\
(0.13831) \\
{[-0.04901]}\end{array}$ & $\begin{array}{l}0.008697 \\
(0.00315) \\
{[2.76098]}\end{array}$ \\
\hline $\begin{array}{l}\text { D } \\
\text { (POPULATION(- } \\
1) \text { ) }\end{array}$ & $\begin{array}{l}574.9397 \\
(414.181) \\
{[1.38814]}\end{array}$ & $\begin{array}{l}-16.34547 \\
(10.7872) \\
{[-1.51527}\end{array}$ & $\begin{array}{l}-14.58656 \\
(8.44938) \\
{[1.72635]}\end{array}$ & $\begin{array}{l}1.993824 \\
(0.19245) \\
{[10.3604]}\end{array}$ \\
\hline $\begin{array}{l}\text { D } \\
\text { (POPULATION(- } \\
2) \text { ) }\end{array}$ & $\begin{array}{l}-917.3912 \\
(899.247) \\
{[-1.02018]}\end{array}$ & $\begin{array}{l}41.35613 \\
(23.4206) \\
{[1.76580]}\end{array}$ & $\begin{array}{l}30.92362 \\
(18.3448) \\
{[1.68568]}\end{array}$ & $\begin{array}{l}-1.439530 \\
(0.41783) \\
{[-3.44527]}\end{array}$ \\
\hline $\begin{array}{l}\text { D } \\
\text { (POPULATION(- } \\
3) \text { ) }\end{array}$ & $\begin{array}{l}682.4348 \\
(877.375) \\
{[0.77781]}\end{array}$ & $\begin{array}{l}-37.31820 \\
(22.8509) \\
{[2.33422]}\end{array}$ & $\begin{array}{l}11.24026 \\
(8.24197) \\
{[1.36378]}\end{array}$ & $\begin{array}{l}0.349115 \\
(0.40767) \\
{[0.85638]}\end{array}$ \\
\hline $\begin{array}{l}\text { D } \\
\text { (POPULATION(- } \\
4) \text { ) }\end{array}$ & $\begin{array}{l}-136.3971 \\
(404.014) \\
{[-0.33761]}\end{array}$ & $\begin{array}{l}24.56161 \\
(10.5224) \\
{[2.33422]}\end{array}$ & $\begin{array}{l}0.496043 \\
(0.36332) \\
{[1.36378]}\end{array}$ & $\begin{array}{l}-0.001850 \\
(0.18772) \\
{[-0.00986]}\end{array}$ \\
\hline $\mathrm{C}$ & $\begin{array}{l}32.67681 \\
(17.8097) \\
{[1.83477]}\end{array}$ & $\begin{array}{l}0.876607 \\
(0.46385) \\
{[1.88986]}\end{array}$ & $\begin{array}{l}0.496043 \\
(0.36332) \\
{[1.365301]}\end{array}$ & $\begin{array}{l}-0.007797 \\
(0.00828) \\
{[-0.94217]}\end{array}$ \\
\hline R-squared & 0.692773 & 0.624266 & 0.765 & 0.980194 \\
\hline Adj. R-squared & 0.417886 & 0.288082 & 0.555 & 0.962473 \\
\hline Sum sq. resids & 12619.18 & 8.559883 & 5.251 & 0.002724 \\
\hline S.E. equation & 25.77144 & 0.671208 & 0.525 & 0.011975 \\
\hline F-statistic & 2.520211 & 1.856919 & 3.645 & 55.31306 \\
\hline Log Likelihood & -160.3937 & -25.41984 & -16.3 & 123.5532 \\
\hline Akaike A/C & 9.642906 & 2.347019 & 1.858 & -5.705580 \\
\hline Schwarz SC & 10.42659 & 3.130708 & 2.642 & -4.921890 \\
\hline Mean Dependent & 25.88804 & -0.185180 & 0.460 & -0.037348 \\
\hline S. D. Dependent & 33.77807 & 0.795504 & 0.788 & 0.061814 \\
\hline \multicolumn{3}{|c|}{ Determinant resid covariance (dof adj.) } & \multicolumn{2}{|c|}{0.0024} \\
\hline \multicolumn{2}{|c|}{ Determinant resid covariance } & \multicolumn{3}{|c|}{0.000173} \\
\hline \multicolumn{2}{|c|}{ Log Likelihood } & \multicolumn{3}{|c|}{-49.71323} \\
\hline \multicolumn{2}{|c|}{ Akaike information criterion } & \multicolumn{3}{|c|}{6.795310} \\
\hline \multicolumn{2}{|c|}{ Schwarz criterion } & \multicolumn{3}{|c|}{10.10422} \\
\hline
\end{tabular}




\section{Vector Error Correction Estimates}

\begin{tabular}{|c|c|c|c|c|}
\hline \multicolumn{5}{|c|}{ 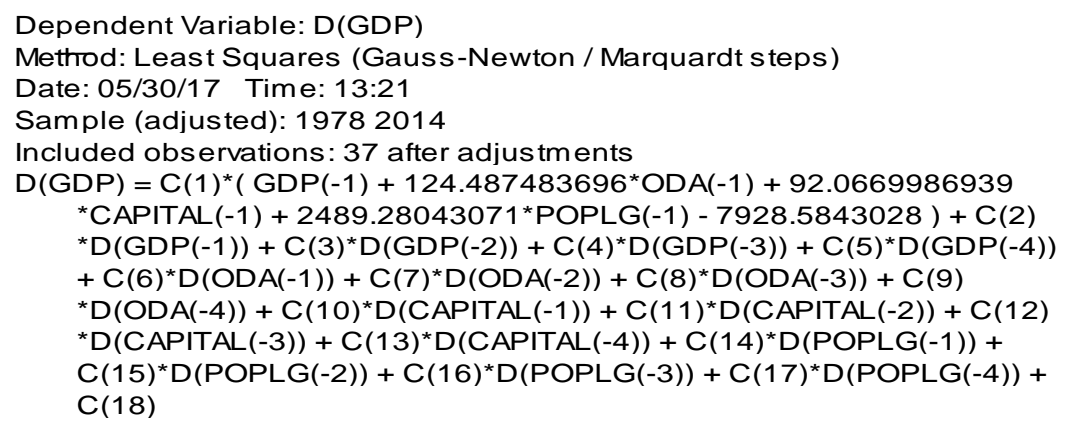 } \\
\hline & Coefficient & Std. Error & t-Statistic & Prob. \\
\hline$C(1)$ & -0.01 & 0.0 & -1.6 & \\
\hline$C(2)$ & 0.192055 & & 0.743635 & 0.4662 \\
\hline$C(3)$ & -0.132601 & 0.219603 & -0.603823 & 0.5531 \\
\hline$C(4)$ & 0.326056 & 0.187894 & 1.735313 & 0.0989 \\
\hline$C(5)$ & -0.021262 & 0.204640 & -0.103901 & 0.9183 \\
\hline$C(6)$ & 0.944205 & & 0.1 & 0.910 \\
\hline$C(7)$ & 2.950476 & 11.39025 & 0.259035 & 0.7984 \\
\hline$C(8)$ & 4.675114 & 9.968084 & 0.469008 & 0.6444 \\
\hline$C(9)$ & 0.230430 & 7.172901 & 0.032125 & 0.9747 \\
\hline$C(10)$ & -8.834268 & 10. & -0.827 & 0.4185 \\
\hline $\mathrm{C}(11)$ & -7.986122 & 9.1 & -0.876074 & 0.35 \\
\hline$C(12)$ & 2.340438 & 7.626244 & 0.306893 & 0.7623 \\
\hline$C(13)$ & 0.218031 & 6.779708 & 0.032159 & 0.9747 \\
\hline$C(14)$ & 574.9397 & 414.1807 & & 0.1812 \\
\hline$C(15)$ & -917.3912 & 899.2467 & -1.020177 & 0.3205 \\
\hline$C(16)$ & 682.4348 & 877.3752 & 0.777814 & 0.4463 \\
\hline $\mathrm{C}(17)$ & -136.3971 & 404.0136 & -0.337605 & 0.7394 \\
\hline $\mathrm{C}(18)$ & 32.67681 & 17.80975 & 1.834772 & 0.0822 \\
\hline \multirow{7}{*}{$\begin{array}{l}\text { R-squared } \\
\text { Adjusted R-squared } \\
\text { S.E. of regression } \\
\text { Sum squared resid } \\
\text { Log likelihood } \\
\text { F-statistic } \\
\text { Prob(F-statistic) }\end{array}$} & 0.692773 & \multicolumn{2}{|c|}{ Mean dependent var } & 25.88804 \\
\hline & 0.417886 & \multicolumn{2}{|c|}{ S.D. dependent var } & 33.77807 \\
\hline & 25.77144 & \multicolumn{2}{|c|}{ Akaike info criterion } & 9.642905 \\
\hline & 12619.18 & \multicolumn{2}{|c|}{ Schwarz criterion } & 10.42659 \\
\hline & -160.3937 & & 9.919192 \\
\hline & 2.520211 & & & 1.891938 \\
\hline & 0.027249 & \multicolumn{2}{|c|}{ Durbin-Wats on stat } & \\
\hline
\end{tabular}

Appendix F: VEC Granger Causality/ Block Exogeneity Wald Tests

\begin{tabular}{|c|c|c|c|}
\hline \multicolumn{4}{|c|}{ Dependent variable: D(GDP) } \\
\hline Excluded & Chi-sq & df & Prob. \\
\hline $\begin{array}{c}\mathrm{D}(\mathrm{ODA}) \\
\mathrm{D}(\mathrm{CAPITAL}) \\
\mathrm{D}(\mathrm{POPLG}) \\
\end{array}$ & $\begin{array}{l}0.454714 \\
2.913232 \\
3.250685 \\
\end{array}$ & $\begin{array}{l}4 \\
4 \\
4 \\
\end{array}$ & $\begin{array}{l}0.9778 \\
0.5724 \\
0.5168 \\
\end{array}$ \\
\hline AlI & 10.42330 & 12 & 0.5789 \\
\hline \multicolumn{4}{|c|}{ Dependent variable: D(ODA) } \\
\hline Excluded & Chi-sa & df & Prob. \\
\hline $\begin{array}{c}\mathrm{D}(\mathrm{GDP}) \\
\mathrm{D}(\mathrm{CAPITAL}) \\
\text { D(POPLG) } \\
\end{array}$ & $\begin{array}{l}6.991891 \\
15.11521 \\
13.57706 \\
\end{array}$ & $\begin{array}{l}4 \\
4 \\
4 \\
\end{array}$ & $\begin{array}{l}0.1363 \\
0.0045 \\
0.0088 \\
\end{array}$ \\
\hline AlI & 22.25028 & 12 & 0.0348 \\
\hline \multicolumn{4}{|c|}{ Dependent variable: D(CAPITAL) } \\
\hline Excluded & Chi-sq & df & Prob. \\
\hline $\begin{array}{c}\text { D(GDP) } \\
\text { D(ODA) } \\
\text { D(POPLG) }\end{array}$ & $\begin{array}{l}6.078254 \\
3.926476 \\
7.677406 \\
\end{array}$ & $\begin{array}{l}4 \\
4 \\
4\end{array}$ & $\begin{array}{l}0.1934 \\
0.4160 \\
0.1041 \\
\end{array}$ \\
\hline AlI & 31.27932 & 12 & 0.0018 \\
\hline \multicolumn{4}{|c|}{ Dependent variable: D(POPLG) } \\
\hline Excluded & Chi-sq & df & Prob. \\
\hline $\begin{array}{c}D(G D P) \\
D(O D A) \\
\text { D(CAPITAL) }\end{array}$ & $\begin{array}{l}2.178736 \\
1.822800 \\
11.49740\end{array}$ & $\begin{array}{l}4 \\
4 \\
4\end{array}$ & $\begin{array}{l}0.7029 \\
0.7683 \\
0.0215 \\
\end{array}$ \\
\hline All & 27.84601 & 12 & 0.0058 \\
\hline
\end{tabular}


Appendix G: Residual Diagnostics

1 Breusch-Godfrey Serial Correlation L M Test

\begin{tabular}{|c|c|c|c|c|}
\hline $\begin{array}{l}\text { F-statistic } \\
\text { Obs* }{ }^{\star} \text {-squared }\end{array}$ & $\begin{array}{l}0.926414 \\
7.329830 \\
\end{array}$ & \multicolumn{2}{|c|}{$\begin{array}{l}\text { Prob. F(4,15) } \\
\text { Prob. Chi-Square (4) }\end{array}$} & $\begin{array}{l}0.4746 \\
0.1195 \\
\end{array}$ \\
\hline \multicolumn{5}{|c|}{$\begin{array}{l}\text { Test Equation: } \\
\text { Dependent Variable: RESID } \\
\text { Method: Least Squares } \\
\text { Date: O5/30/17 Time: } 14: 13 \\
\text { Sample: } 1978 \text { 2014 } \\
\text { Included observations: } 37 \\
\text { Presample missing value lagged residuals set to zero. }\end{array}$} \\
\hline Variable & Coefficient & Std. Error & t-Statis tic & Prob. \\
\hline$C(1)$ & 0.018832 & 0.070014 & 0.268982 & 0.7916 \\
\hline$C(2)$ & 0.760697 & 3.267906 & 0.232778 & 0.8191 \\
\hline$C(3)$ & -0.169576 & 0.822695 & -0.206123 & 0.8395 \\
\hline$C(4)$ & 0.256660 & 0.646442 & 0.397035 & 0.6969 \\
\hline$C(5)$ & -0.162085 & 1.089713 & -0.148741 & 0.8837 \\
\hline$C(6)$ & -6.310117 & 9.289973 & -0.679240 & 0.5073 \\
\hline$C(7)$ & -7.948015 & 14.58463 & -0.544958 & 0.5938 \\
\hline $\mathrm{C}(8)$ & -6.127644 & 12.02688 & -0.509496 & 0.6178 \\
\hline$C(9)$ & -5.035852 & 12.79780 & -0.393494 & 0.6995 \\
\hline$C(10)$ & -6.649461 & 13.64556 & -0.487298 & 0.6331 \\
\hline$C(11)$ & 6.855772 & 34.09074 & 0.201104 & 0.8433 \\
\hline C(12) & 7.840021 & 31.75620 & 0.246882 & 0.8083 \\
\hline$C(13)$ & 0.465407 & 7.692474 & 0.060502 & 0.9526 \\
\hline C(14) & 15.23944 & 438.5801 & 0.034747 & 0.9727 \\
\hline$C(15)$ & -726.7694 & 1913.512 & -0.379809 & 0.7094 \\
\hline$C(16)$ & 1024.182 & 2425.276 & 0.422295 & 0.6788 \\
\hline$C(17)$ & -530.9792 & 1511.716 & -0.351243 & 0.7303 \\
\hline$C(18)$ & -32.49555 & 118.4548 & -0.274329 & 0.7876 \\
\hline RESID (-1) & -0.920582 & 3.344450 & -0.275257 & 0.7869 \\
\hline RESID (-2) & -0.190278 & 0.381904 & -0.498237 & 0.6255 \\
\hline RESID $(-3)$ & -0.509558 & 0.390503 & -1.304876 & 0.2116 \\
\hline RESID $(-4)$ & -0.480914 & 0.401685 & -1.197243 & 0.2498 \\
\hline R-squared & 0.198104 & \multirow{7}{*}{\multicolumn{2}{|c|}{$\begin{array}{l}\text { Mean dependent var } \\
\text { S.D. dependent var } \\
\text { Akaike info criterion } \\
\text { Schwarz criterion } \\
\text { Hannan-Quinn criter. } \\
\text { Durbin-Watson stat }\end{array}$}} & 0.000000 \\
\hline Adjusted R-squared & -0.924552 & & & 18.72252 \\
\hline S.E. of regression & 25.97341 & & & 9.638346 \\
\hline Sum squared resid & 10119.27 & & & 10.59619 \\
\hline Log likelihood & -156.3094 & & & 9.976030 \\
\hline F-statistic & 0.176460 & & & 2.082360 \\
\hline Prob(F-statistic) & 0.999818 & & & \\
\hline
\end{tabular}

\section{Heteroskedasticity Tests \\ Breusch-Pagan-Godfrey}

Heteroskedasticity Test: Breusch-Pagan-Godfrey

\begin{tabular}{|c|c|c|c|c|}
\hline $\begin{array}{l}\text { F-statistic } \\
\text { Obs }{ }^{\star} R-\text {-s quared } \\
\text { Scaled explained SS }\end{array}$ & $\begin{array}{l}1.047583 \\
20.97907 \\
7.501930\end{array}$ & \multicolumn{2}{|c|}{$\begin{array}{l}\text { Prob. } \mathrm{F}(20,16) \\
\text { Prob. Chi-Square(20) } \\
\text { Prob. Chi-Square }(20)\end{array}$} & $\begin{array}{l}0.4686 \\
0.3984 \\
0.9947\end{array}$ \\
\hline \multicolumn{5}{|c|}{$\begin{array}{l}\text { Test Equation: } \\
\text { Dependent Variable: RESID^2 } \\
\text { Method: Least Squares } \\
\text { Date: 05/30/17 Time: } 14: 16 \\
\text { Sample: } 1978 \text { 2014 } \\
\text { Included observations: } 37\end{array}$} \\
\hline Variable & Coefficient & Std. Error & t-Statis tic & Prob. \\
\hline C & -4022.146 & 5353.060 & -0.751373 & 0.4633 \\
\hline $\operatorname{GDP}(-1)$ & -2.295792 & 6.225320 & -0.368783 & 0.7171 \\
\hline ODA $(-1)$ & -186.8592 & 194.6259 & -0.960094 & 0.3513 \\
\hline CAPITAL $(-1)$ & 170.4243 & 278.9498 & 0.610950 & 0.5498 \\
\hline POPLG(-1) & -647.3674 & 9708.019 & -0.066684 & 0.9477 \\
\hline $\operatorname{GDP}(-2)$ & -2.677819 & 7.849666 & -0.341138 & 0.7374 \\
\hline GDP $(-3)$ & 7.695602 & 6.487008 & 1.186310 & 0.2528 \\
\hline $\operatorname{GDP}(-4)$ & -6.905654 & 7.133606 & -0.968045 & 0.3474 \\
\hline GDP (-5) & 7.919689 & 5.455991 & 1.451558 & 0.1660 \\
\hline ODA $(-2)$ & 128.1970 & 217.4604 & 0.589519 & 0.5637 \\
\hline ODA $(-3)$ & -115.4529 & 222.4529 & -0.518999 & 0.6109 \\
\hline $\operatorname{ODA}(-4)$ & 219.5739 & 192.0088 & 1.143562 & 0.2696 \\
\hline ODA $(-5)$ & 238.5780 & 186.6494 & 1.278215 & 0.2194 \\
\hline CAPITAL $(-2)$ & -234.5552 & 311.9238 & -0.751963 & 0.4630 \\
\hline CAPITAL $(-3)$ & 228.8284 & 257.3921 & 0.889027 & 0.3872 \\
\hline CAPITAL $(-4)$ & -202.2138 & 240.7063 & -0.840085 & 0.4132 \\
\hline CAPITAL $(-5)$ & 151.7398 & 157.2671 & 0.964854 & 0.3490 \\
\hline POPLG(-2) & 354.0182 & 28946.88 & 0.012230 & 0.9904 \\
\hline POPLG(-3) & 7822.916 & 38353.49 & 0.203969 & 0.8409 \\
\hline POPLG(-4) & -10393.10 & 27361.20 & -0.379848 & 0.7091 \\
\hline POPLG(-5) & 2810.952 & 8827.230 & 0.318441 & 0.7543 \\
\hline R-squared & 0.567002 & \multirow{7}{*}{\multicolumn{2}{|c|}{$\begin{array}{l}\text { Mean dependent var } \\
\text { S.D. dependent var } \\
\text { Akaike info criterion } \\
\text { Schwarz criterion } \\
\text { Hannan-Quinn criter. } \\
\text { Durbin-Wats on stat }\end{array}$}} & 341.0588 \\
\hline Adjusted R-squared & 0.025754 & & & 569.4236 \\
\hline S.E. of regression & 562.0433 & & & 15.79784 \\
\hline Sum squared resid & 5054283. & & & 16.71215 \\
\hline Log likelihood & -271.2601 & & & 16.12018 \\
\hline F-statistic & 1.047583 & & & 2.471773 \\
\hline Prob(F-statistic) & 0.468576 & & & \\
\hline
\end{tabular}




\section{Harvey}

\begin{tabular}{|c|c|c|c|c|}
\hline $\begin{array}{l}\text { F-statistic } \\
\text { Obs-R-squared } \\
\text { Scaled explained SS }\end{array}$ & $\begin{array}{l}1.661351 \\
24.97409 \\
30.42615 \\
\end{array}$ & \multicolumn{2}{|c|}{$\begin{array}{l}\text { Prob. } F(20,16) \\
\text { Prob. Chi-Square(20) } \\
\text { Prob. Chi-Square(20) }\end{array}$} & \multirow[t]{2}{*}{$\begin{array}{l}0.1532 \\
0.2024 \\
0.0632 \\
\end{array}$} \\
\hline $\begin{array}{l}\text { Test Equation: } \\
\text { Dependent Variable: } \\
\text { Method: Least Square } \\
\text { Date: O5/30/17 Time } \\
\text { Sample: 1978 2014 } \\
\text { Included observations }\end{array}$ & $\begin{array}{l}\mathrm{D} 2 \\
3\end{array}$ & & & \\
\hline Variable & Coefficient & Std. Error & t-Statistic & Prob. \\
\hline 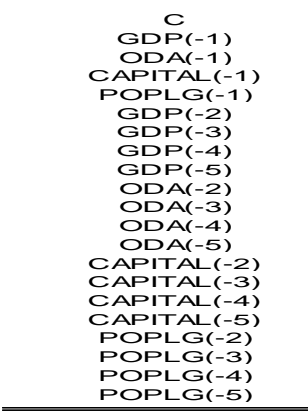 & $\begin{array}{r}8.244155 \\
-0.028725 \\
-1.458669 \\
-0.665133 \\
23.59535 \\
-0.003045 \\
0.051833 \\
-0.027703 \\
0.027118 \\
-1.134605 \\
0.863611 \\
1.260613 \\
-0.210078 \\
-1.180052 \\
1.879983 \\
-1.179576 \\
0.808679 \\
-86.76647 \\
140.1535 \\
-100.6748 \\
24.21549 \\
\end{array}$ & $\begin{array}{l}20.24627 \\
0.023545 \\
0.736111 \\
1.055040 \\
36.71753 \\
0.029689 \\
0.024535 \\
0.026981 \\
0.020636 \\
0.822475 \\
0.841358 \\
0.726213 \\
0.705943 \\
1.179754 \\
0.973505 \\
0.910396 \\
0.594813 \\
109.4825 \\
145.0600 \\
103.4851 \\
33.38622 \\
\end{array}$ & $\begin{array}{r}0.407194 \\
-1.219967 \\
-1.981589 \\
-0.630434 \\
-0.642618 \\
-0.102576 \\
2.112591 \\
-1.026779 \\
1.314139 \\
-1.379500 \\
1.026449 \\
1.735873 \\
-0.297585 \\
-1.000253 \\
1.931149 \\
-1.295674 \\
1.359551 \\
-0.792515 \\
-0.966176 \\
-0.972843 \\
0.725314 \\
\end{array}$ & $\begin{array}{l}0.6893 \\
0.24002 \\
0.0650 \\
0.5373 \\
0.5296 \\
0.9196 \\
0.0507 \\
0.3198 \\
0.20773 \\
0.1867 \\
0.3199 \\
0.1018 \\
0.7698 \\
0.3321 \\
0.0714 \\
0.2135 \\
0.1928 \\
0.4397 \\
0.3483 \\
0.3451 \\
0.4787 \\
\end{array}$ \\
\hline $\begin{array}{l}\text { R-squared } \\
\text { Adjusted R-squared } \\
\text { S.E. of regression } \\
\text { Sum squared resid } \\
\text { Log likelihood } \\
\text { F-statistic } \\
\text { Prob(F-s tatistic) }\end{array}$ & $\begin{array}{r}0.674975 \\
0.268694 \\
2.125752 \\
72.30115 \\
-64.89428 \\
1.661351 \\
0.153242\end{array}$ & \multicolumn{2}{|c|}{$\begin{array}{l}\text { Mean dependent var } \\
\text { S.D. dependent var } \\
\text { Akaike info criterion } \\
\text { Schwarz Criterion } \\
\text { Hannan-Quinn criter } \\
\text { Durbin-Watson stat }\end{array}$} & $\begin{array}{l}4.061506 \\
2.485783 \\
4.642934 \\
5.557239 \\
4.965279 \\
2.415947\end{array}$ \\
\hline
\end{tabular}

\section{ARCH}

Heteroskedasticity Test: ARCH

\begin{tabular}{|c|c|c|c|c|}
\hline $\begin{array}{l}\text { F-statistic } \\
\text { Obs }{ }^{\star} R \text {-squared }\end{array}$ & $\begin{array}{l}0.843695 \\
3.549594 \\
\end{array}$ & \multicolumn{2}{|c|}{$\begin{array}{l}\text { Prob. } F(4,28) \\
\text { Prob. Chi-Square (4) }\end{array}$} & $\begin{array}{l}0.5094 \\
0.4704 \\
\end{array}$ \\
\hline \multicolumn{5}{|c|}{$\begin{array}{l}\text { Test Equation: } \\
\text { Dependent Variable: RESID^2 } \\
\text { Method: Least Squares } \\
\text { Date: 05/30/17 Time: } 14: 27 \\
\text { Sample (adjusted): } 19822014 \\
\text { Included observations: } 33 \text { after adjus tments } \\
\end{array}$} \\
\hline Variable & Coefficient & Std. Error & t-Statistic & Prob. \\
\hline $\begin{array}{l}c \\
\text { RESID^2(-1) } \\
\text { RESID^2(-2) } \\
\text { RESID^2(-3) } \\
\text { RESID^2(-4) }\end{array}$ & $\begin{array}{r}280.1903 \\
0.302805 \\
-0.015255 \\
0.227692 \\
-0.228803 \\
\end{array}$ & $\begin{array}{l}160.9962 \\
0.193264 \\
0.202813 \\
0.255746 \\
0.258363 \\
\end{array}$ & $\begin{array}{r}1.740353 \\
1.566797 \\
-0.075215 \\
0.890306 \\
-0.885588 \\
\end{array}$ & $\begin{array}{l}0.0928 \\
0.1284 \\
0.9406 \\
0.3809 \\
0.3834\end{array}$ \\
\hline $\begin{array}{l}\text { R-squared } \\
\text { Adjusted R-squared } \\
\text { S.E. of regression } \\
\text { Sum squared resid } \\
\text { Log likelihood } \\
\text { F-statistic } \\
\text { Prob(F-statistic) }\end{array}$ & $\begin{array}{r}0.107563 \\
-0.019927 \\
598.3766 \\
10025528 \\
-255.1232 \\
0.843695 \\
0.509383\end{array}$ & \multicolumn{2}{|c|}{$\begin{array}{l}\text { Mean dependent var } \\
\text { S.D. dependent var } \\
\text { Akaike info criterion } \\
\text { Schwarz criterion } \\
\text { Hannan-Quinn criter. } \\
\text { Durbin-Wats on stat }\end{array}$} & $\begin{array}{l}378.9030 \\
592.5022 \\
15.76505 \\
15.99179 \\
15.84134 \\
1.944376\end{array}$ \\
\hline
\end{tabular}

\section{Hisgram -Normality Test}

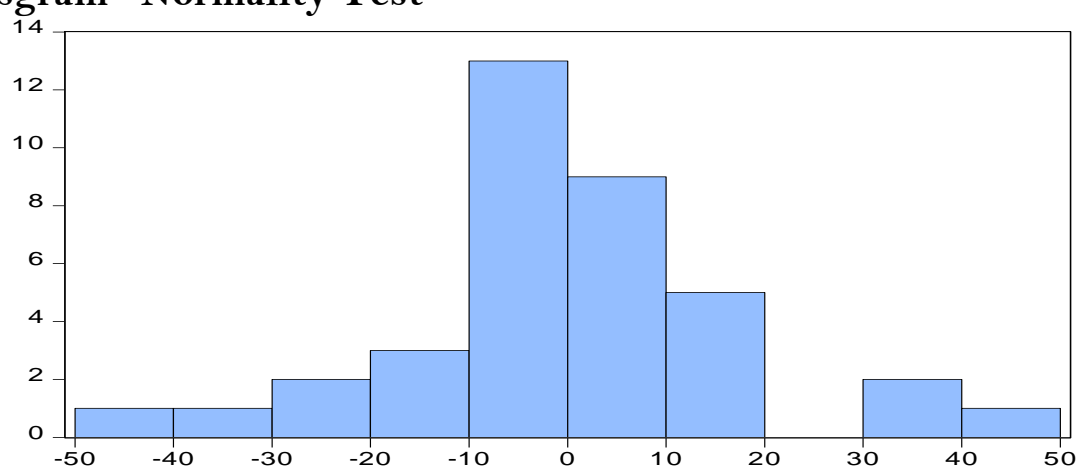

Series: Residuals Sample 19782014 Observations 37

Mean 0.000000 Median $\quad-1.413219$ Maximum $\quad \mathbf{4 5 . 4 6 9 5 8}$ Minimum $\quad-46.67750$ Std. Dev. 18.72252 Skewness $\quad 0.102723$ Kurtosis $\quad 3.712146$

Jarque-Bera 0.846931 Probability

\section{Appendix H: Wald Test}

Null Hypothesis: $\Delta \mathrm{ODA}_{\mathrm{t}-1}=\Delta \mathrm{ODA}_{\mathrm{t}-2}=\Delta \mathrm{ODA}_{\mathrm{t}-3}=\Delta \mathrm{ODA}_{\mathrm{t}-\mathrm{t}}=0$

\begin{tabular}{l|l|l|l}
\hline Test Statistic & Value & df & Probability \\
\hline F-statistic & 0.113678 & $(4,19)$ & 0.9761 \\
\hline Chi-square & 0.454714 & 4 & 0.9778 \\
\hline Null Hypothesis Summary & \multicolumn{3}{|l}{} \\
\hline Normalised Restriction (=0) & Value & Std. Err. \\
\hline$\Delta \mathrm{ODA}_{\mathrm{t}-1}$ & 0.944205 & 8.258765 \\
\hline$\Delta \mathrm{ODA}_{\mathrm{t}-2}$ & & 2.950476 & 11.39025 \\
\hline$\Delta \mathrm{ODA}_{\mathrm{t}-3}$ & 4.675114 & 9.968084 \\
\hline$\Delta \mathrm{ODA}_{\mathrm{t}-4}$ & & 0.230430 & 7.172901 \\
\hline
\end{tabular}

Restrictions are linear in coefficient 